\title{
RESEARCH
}

Open Access

\section{What is a tree in the Mediterranean Basin hotspot? A critical analysis}

Frédéric Médail ${ }^{* *}$ (D), Anne-Christine Monnet ${ }^{1}$, Daniel Pavon', Toni Nikolic², Panayotis Dimopoulos ${ }^{3}$, Gianluigi Bacchetta ${ }^{4}$, Juan Arroyo ${ }^{5}$, Zoltán Barina ${ }^{6}$, Marwan Cheikh Albassatneh7, Gianniantonio Domina ${ }^{8}$, Bruno Fady ${ }^{9}$, Vlado Matevski ${ }^{10}$, Stephen Mifsud ${ }^{11}$ and Agathe Leriche ${ }^{1}$

\begin{abstract}
Background: Tree species represent 20\% of the vascular plant species worldwide and they play a crucial role in the global functioning of the biosphere. The Mediterranean Basin is one of the 36 world biodiversity hotspots, and it is estimated that forests covered $82 \%$ of the landscape before the first human impacts, thousands of years ago. However, the spatial distribution of the Mediterranean biodiversity is still imperfectly known, and a focus on tree species constitutes a key issue for understanding forest functioning and develop conservation strategies.

Methods: We provide the first comprehensive checklist of all native tree taxa (species and subspecies) present in the Mediterranean-European region (from Portugal to Cyprus). We identified some cases of woody species difficult to categorize as trees that we further called "cryptic trees". We collected the occurrences of tree taxa by "administrative regions", i.e. country or large island, and by biogeographical provinces. We studied the species-area relationship, and evaluated the conservation issues for threatened taxa following IUCN criteria.
\end{abstract}

Results: We identified 245 tree taxa that included 210 species and 35 subspecies, belonging to 33 families and 64 genera. It included 46 endemic tree taxa (30 species and 16 subspecies), mainly distributed within a single biogeographical unit. The countries with the highest tree richness are Greece (146 taxa), Italy (133), Albania (122), Spain (155), Macedonia (116), and Croatia (110). The species-area relationship clearly discriminated the richest central-eastern (Balkans) and northern (Alpine and Cevenno-Pyrenean) biogeographical provinces, against the five western provinces in the Iberian Peninsula. We identified 44 unrecognized "cryptic trees", representing $21 \%$ of the total trees. Among the 245 taxa identified, 19 are considered to be threatened (15 CR + EN + VU) or near threatened (4 NT) by IUCN.

Conclusions: The Mediterranean-European region includes an unsuspectedly high number of tree taxa, almost 200 tree taxa more than in the central European region. This tree diversity is not distributed evenly and culminates in the central-eastern part of the Mediterranean region, whereas some large Tyrrhenian islands shelter several narrow endemic tree taxa. Few taxa are recognized as threatened in the IUCN Red list, and the vulnerability of these species is probably underestimated.

Keywords: Plant biogeography, Mediterranean region, Threatened trees, Tree definition, Tree distributions

\footnotetext{
* Correspondence: frederic.medail@imbe.fr

${ }^{1}$ Aix Marseille Univ, Avignon Univ, CNRS, IRD, IMBE. Technopôle de

l'Arbois-Méditerranée, cedex 4, BP 80, 13545 Aix-en-Provence, France

Full list of author information is available at the end of the article
} 


\section{Background}

A recent census of the biomass distribution on Earth indicates that plants, mostly terrestrial species, represent about $80 \%$ (i.e. $\approx 450 \mathrm{Gt} \mathrm{C}$ ) of the sum of the biomass across all taxa worldwide, and that plant biomass includes about $70 \%$ stems and tree trunks (Bar-On et al. 2018). This result underlines the crucial role of trees in the global functioning of the biosphere. With ca. 60,000 tree species representing $20 \%$ of the vascular plant species worldwide according to GlobalTreeSearch (Beech et al. 2017), trees constitute a major component of the structure and function of forest ecosystems located in temperate and tropical biomes. Higher levels of ecosystem services, such as biomass production, water supply, nutrient cycling and soil carbon storage, characterize forests with a higher tree diversity (Gamfeldt et al. 2013). Since forests play a crucial role in the conservation of terrestrial biodiversity by providing habitats and ecological niches for a majority of plants and animals (www.globaltrees.org), it is necessary that assessments of the different tree taxa involved into the composition of ecosystems should be comprehensive and robust by including a biogeographical perspective.

Nevertheless, the global knowledge of the number and distribution of tree species remains surprisingly low both at the international level (Beech et al. 2017) and for large biogeographic areas (regions and provinces). While threats on the tropical forests urge the scientists to fill the gap in knowledge on their diversity (Serra-Diaz et al. 2017), the five Mediterranean ecoregions (Mediterranean Basin, California, central Chile, Cape Region of South Africa and south-western Australia) still require further studies. With only $2 \%$ of the world's terrestrial surface, Mediterranean ecoregions contain nearly 20\% of the Earth's total plant diversity, making very significant biodiversity hotspots, second only after tropical ones (Cowling et al. 2005). The Mediterranean Basin is one of these 36 current biodiversity hotspots worldwide (Médail and Myers 2004), including both regional (Médail and Quézel 1997) and local hotspots, i.e. micro- and nano-hotspots sensu Cañadas et al. (2014). It is estimated that Mediterranean forests covered $82 \%$ of the landscape before the beginnings of human impacts on ecosystems thousands of years ago (WWF 2001). But the whole Mediterranean Basin still comprises a high tree richness estimated to 290 indigenous taxa (species and subspecies) including 201 endemics (Quézel and Médail 2003; Médail 2008). The spatial distribution of this woody plant biodiversity is still imperfectly known even in Mediterranean-European region. A biogeographical focus on tree species distribution is needed for conservation of the Mediterranean forests which have undergone rapid changes in structure and composition in recent decades (Mazzoleni et al. 2004), even if forest surface remains stable on the global scale (FAO and Plan Bleu 2018).

Among the woody diversity, the definition of a tree per se might be problematic and requires some agreement (e.g. Gschwantner et al. 2009). This is especially the case for historically disturbed tree species that often appears as shrubs and display as true trees only after a long period without disturbance or in cultivation in gardens. This aspect is particularly important in the Mediterranean region where the impacts of natural and human disturbances are both very old and severe.

In this study, we provide the first checklist of all tree taxa (species and subspecies) present in the northern part of the Mediterranean ecoregion (i.e. the Mediterranean-European region), since Mediterranean forests occur mainly in this area (in Europe, forests cover ca. 33\% of total land area: see Alberdi Asensio et al. 2015) and the available data are more robust and readily available there than in the southern and south-eastern Mediterranean.

Therefore, the main objectives of this study are: (i) to examine whether an extensive survey of the whole putative tree taxa challenge the definition of what is generally considered as a Mediterranean tree; (ii) to provide a comprehensive checklist of tree taxa for the Mediterranean-European region, i.e. from Portugal to Cyprus; (iii) to examine the global spatial distribution of tree taxonomic diversity (natives and endemics) at the biogeographical and administrative scales. Finally, we compared the distribution of tree diversity in the Mediterranean-European region from previous assessment made in the whole Mediterranean Basin and the European continent and discussed the implications for conservation.

\section{Methods}

Study area

We defined the Mediterranean-European region as the North Mediterranean terrestrial ecoregion following the definition of terrestrial ecoregions of the world from Olson et al. (2001) (Fig. 1). They provide a biogeographic scheme defined by existing global maps of floristic provinces and by regional maps of units based on the distribution of selected groups of plants and on published regional classification systems of terrestrial habitats. The biogeographical limits for the Mediterranean region are similar to those proposed by Médail and Quézel (1997), except for some areas of the mountain ridge of the Italian peninsula and of the Balkans. Indeed, climate indices are not strictly relevant to define the biogeographical limits per se, notably for the upper parts of the Mediterranean mountains.

Total covered area, including islands, is $1,610,200 \mathrm{~km}^{2}$, with coastline of approximatively $45,200 \mathrm{~km}$. The orographic variation in the area is large, and the altitudes 


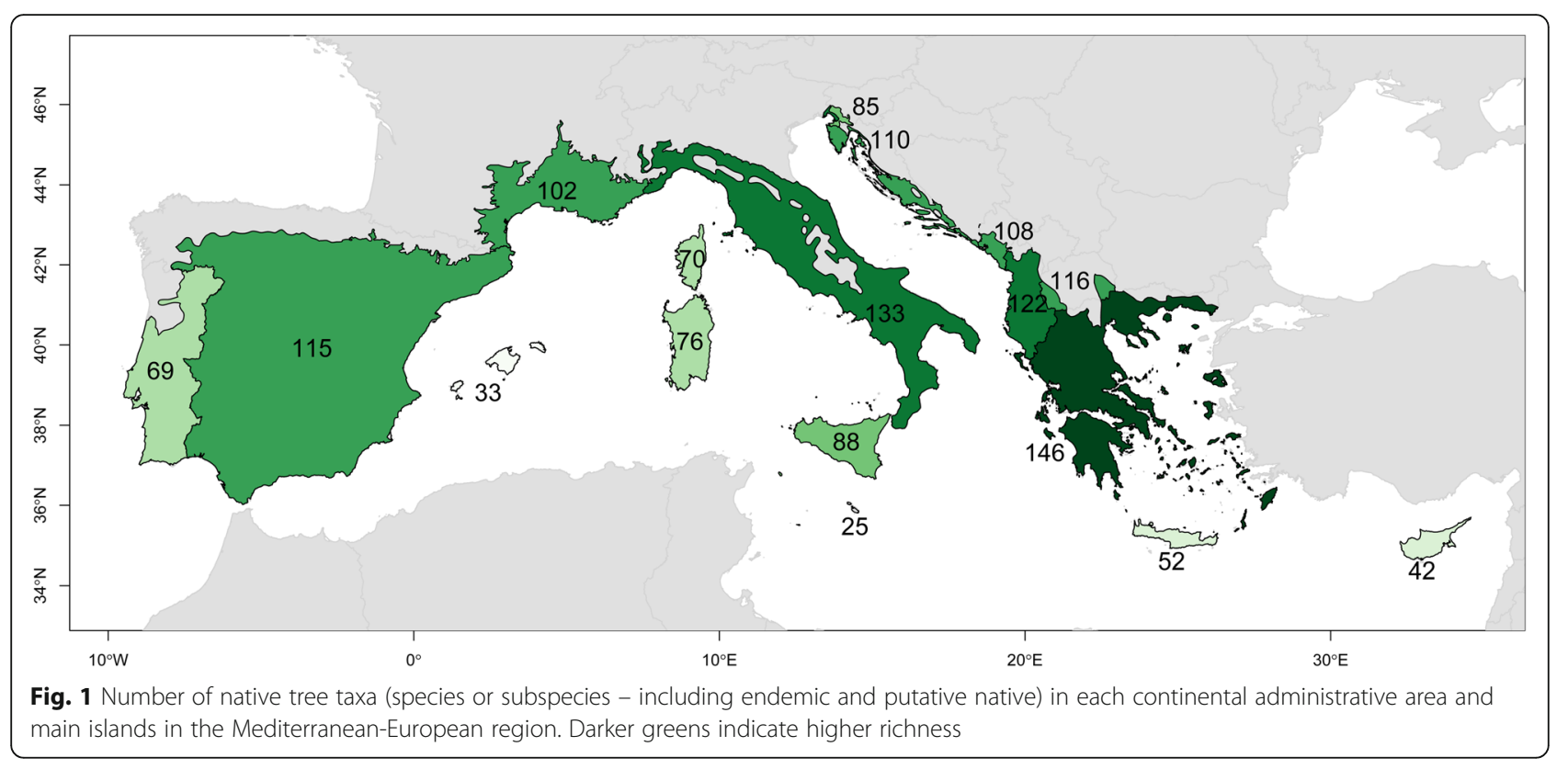

range from $0 \mathrm{~m}$ a.s.l. up to $3482 \mathrm{~m}$ a.s.l. (Mulhacén, Sierra Nevada - Spain).

The study area covers the following countries (as administrative units) from west to east: Portugal, Spain, France, Italy, Malta, Slovenia, Croatia, Montenegro, Albania, Macedonia, Greece and Cyprus. Larger Mediterranean islands (in addition to Malta and Cyprus) corresponding to the Balearic archipelago, Corsica, Sardinia, Sicily and Crete, are treated as independent units to achieve a better spatial resolution of tree taxa and island specificities. The study area does not include the non-European Mediterranean area, i.e. North Africa and Near East.

The area is characterized by a Mediterranean climate types marked by mild and humid winters, hot and dry summers and a relative long period of aridity each year which impose an effective and severe drought on the plants. Rainfall patterns and the oceanity are extremely varied, and this explain why the Mediterranean Basin is characterized by the lowest rainfall reliability (quantified as interannual variations in monthly and seasonal rainfalls, and as the frequency of individual rainfalls) of the five Mediterranean-climate ecosystems of the world (Cowling et al. 2005). In general, annual rainfalls are greater in the northern than in the southern areas of the Mediterranean Basin and increase with elevation in the mountain ranges. During moist season the rainfall can be unpredictable and often intense from autumn through spring.

Mediterranean vegetation types vary widely with environmental constraints (climate, geology, geomorphology, soil type), dominant plant species, and disturbances induced by man and its herds. The woody vegetation is constituted by diverse types of matorrals or shrublands (maquis, garrigue, phrygana) and forests. In relation to the bioclimate type and the altitude, several major types of this vegetation can be recognized in the MediterraneanEuropean region (Quézel and Médail 2003; Rivas-Martínez et al. 2007; Médail 2008): (i) a thermo-Mediterranean belt from sea level to $\sim 200-500(800) \mathrm{m}$ a.s.l., dominated by sclerophyllous communities most often as a narrow strip along the coast (with Olea europaea, Ceratonia siliqua, Chamaerops humilis, Pistacia lentiscus, Pinus halepensis, Pinus brutia, etc.); (ii) a meso-Mediterranean belt, between $\sim 100-500(1000) \mathrm{m}$ a.s.l., mainly with sclerophyllous forests (Quercus ilex, Quercus suber and Q. coccifera) or Pinus halepensis/P. brutia forests in areas with low rainfall or formerly disturbed by man; (iii) a supra-Mediterranean belt, between $\sim 500-1500(1800) \mathrm{m}$ a.s.l., with diverse deciduous oaks forests (including Acer, Carpinus, Ostrya, Quercus and Sorbus) in the more humid ombrotypes; (iv) a mountain-Mediterranean level ( 15002000 m a.s.l.) including Fagus and deciduous and semi-deciduous Quercus forests and notably coniferous forests with Pinus nigra, Pinus sylvestris and firs (Abies alba and most of the Mediterranean Abies spp.) and even cedar (Cedrus libani s.l.) on Cyprus.

An extremely important feature of this woody Mediterranean vegetation is that it has been dramatically influenced by human activities for thousands of years (e.g. Thirgood 1981; Blondel et al. 2010). Forest logging, fires, grazing, agriculture development, soil disturbances, excessive uptake of water to the detriment of riparian trees, changes in the distribution of native species due to large reforestations, aforestations, and introductions of alien taxa led to massive landscape transformations and changes in the structure and dynamics of these natural forest ecosystems (Quézel and Médail 2003; Blondel 2006). 
Mediterranean islands are in this respect of particular concern, due to the higher threat they suffer, as a combination of higher typical sensitivity to disturbances, and long history of human occupancy (e.g. Médail 2017). For this reason, we considered larger islands as separate units in our analysis.

\section{Tree definition}

The IUCN's Global Tree Specialist Group (GTSG) defines a tree as " $a$ woody plant with usually a single stem growing to a height of at least two meters, or if multi-stemmed, then at least one vertical stem five centimeters in diameter at breast height" (Beech et al. 2017). Our definition is slightly different and we define as tree the plants with the following biological features: (i) secondary growth (Fahn 1990); (ii) perennials (they live many years, mostly for decades or centuries); (iii) typically (at least in some environmental conditions or locations) having a single stem or trunk, growing orthotropic with monopodial or more often sympodial branching systems, and bearing lateral branches at some distance from the ground; and (iv) the height of the mature individual is at least three meters. Such plants correspond to the growth-form "phanerophytes" according to Raunkiær (1934) and Ellenberg et al. (1991) (originally P, excluding NP = nanophanerophytes, height $0,5-5 \mathrm{~m}$ ), or phanerophytes "scapose" (originally Pscap), phanerophytes "caespitose" (originally Pcaesp) and phanerophytes "striscianti" (originally Prept) according to Pignatti (1982).

By strictly following those criteria, we identified some cases of woody species difficult to categorize that we further called "cryptic trees". Indeed, this definition includes some taxa that generally occur as shrubs with poorly defined multicolous stems but can form true trees under certain environmental conditions or in situations where the disturbances have been absent or very reduced for at least several decades. Surprisingly, it turned out that these cases were not rare in the study area. This is the case for instance of Spartium junceum or Genista etnensis (Fabaceae) which usually grows in the form of a bush (nanophanerophyte) of less than $5 \mathrm{~m}$ high. We included them in the checklist because in some localities of Corsica, Sardinia and Sicily (Aeolian islands) these taxa meet the above criteria of tree. Many of the tree species reported in this study may very frequently appear as shrubs or even prostrate scrubs due to intense disturbance, particularly herbivory.

\section{Occurrences and status by administrative or by biogeographical areas}

Occurrences of each tree taxa were compiled (i) by country $(n=12)$ and large island $(n=5)$ (hereafter, "administrative regions"), and (ii) by biogeographical provinces. To date, a finer spatial approach is not available for all taxa per countries throughout the study area.
The definition of the biogeographical provinces followed the Biogeographic map of Europe provided by Rivas-Martínez et al. (2004). Hence, thirteen biogeographic provinces occur in the study area (Fig. 3a). Three of them are included into the Eurosiberian biogeographical region but are representative of transition zones between the Mediterranean and the Eurosiberian regions (Cevenno-Pyrenean, Alpine, and Apennino-Balkan); the other ten are included in the Mediterranean region. We studied the species-area relationship within the administrative or biogeographical regions by plotting the total native tree taxa richness of each geographic unit as a function of their surface, after log transformation.

For each species or subspecies, the presence in each administrative or biogeographical unit, was defined as native $(\mathrm{N})$ or introduced (I). We consider endemic tree taxa as range-restricted taxa in and outside of the study area, in general located within a unique biogeographical province sensu Rivas-Martínez et al. (2004).

We marked taxa with unclear autochthonous or allochthonous origin as putative native (i.e. "N?", e.g. Tetraclinis articulata in Malta), or putative introduced (i.e. "I?"). Taxa for which the presence is not confirmed but possible were quoted as putative presence (i.e."?", e.g. Crataegus pentagyna in Montenegro). Many cultivated and sometime naturalized tree species have not been considered. We focused only to a small number of taxa that have been cultivated for a long period (archeophytes, i.e. present before the classical date of the "discovery" of America in 1492) and, apart from culture, are widely naturalized in some parts of the studied area but also native in some areas of the Mediterranean-European region i.e. Castanea sativa Mill., Ceratonia siliqua L., Cupressus sempervirens L., Ficus carica L., Juglans regia L., etc. (see Additional file 1). We considered threatened tree taxa using the IUCN (2018) classification system, as taxa included into the three classes: critically endangered (CR), endangered (EN), or vulnerable (VU). The other categories included near threatened taxa (NT), least concern taxa (LC), and data deficient taxa (DD) are also considered in the present work.

\section{Data sources}

The data were collected and aggregated for each country and large island. The primary sources of data were the international database Euro + Med PlantBase (http://www.emplantbase.org/home.html), Flora Europaea (Tutin et al. 1964-1993), and the volume series Chorology of trees and shrubs in south-west Asia and adjacent regions (Browicz 1982-1996). These comprehensive data were carefully completed and checked with available national floras, national databases, regional databases, other publications, and our own expertise, when the aforementioned sources were not available: Albania (Barina et al. 2017; Z. Barina pers. comm.), 
Corsica (Jeanmonod and Gamisans 2013; CBN Corse pers. comm.), Crete (Chilton and Turland 1997; http:// www.cretanflora.com/; Strid 2016), Croatia (Nikolić 2004-onward), Cyprus (Hand et al. 2011-onward), continental France (Silene-Flore database: http://flore.silene.eu, IGN Inventaire Forestier: http://inventaire-forestier.ign.fr/, Tison et al. 2014), Greece (Dimopoulos et al. 2013, 2016; Strid 2016), Iberian Peninsula i.e. Balearic Islands, Spain and Portugal (Anthos: http://www.anthos.es; Castroviejo 1986-2015; Sociedade Portuguesa de Botânica 2014), Italy (Bartolucci et al. 2018; Galasso et al. 2018; Vegitaly: http:// www.vegitaly.it/), Macedonia (V. Matevski ined.), Malta (Mazzocchi 1969; Baldacchino and Stevens 2000; Mifsud 2002-2014; Casha 2015; Baldacchino 2018; Calleja 2018); Montenegro (F. Médail \& A.-C. Monnet obs. pers.), Sardinia (Arrigoni 2006-2015; Bacchetta et al. 2012; G. Bacchetta obs. pers.), Sicily (Giardina et al. 2007), Slovenia (Jogan et al. 2001).

In addition, some other more thematic and comprehensive data sources were used such as the European Atlas of Forest (San-Miguel-Ayanz et al. 2016) and completed by some recent papers concerning the description of some new tree taxa, such as Tamarix minoa in Crete (Villar et al. 2015) or two cryptic species in the Alnus glutinosa group (Vít et al. 2017). Data synthesis was led by D. Pavon \& F. Médail between 2014 and 2018.

\section{Taxonomy and nomenclature}

The present checklist of Mediterranean-European trees includes only the taxa at the species and subspecies levels which meet both criteria: "study area" and "tree definition". This list does not contain other sub-specific levels, such as varieties, forms, or hybrids, because of their taxonomical and nomenclatural instabilities. We followed the classification of the Angiosperm Phylogeny Group for the definition of families (APG III 2009; APG IV 2016). The nomenclature of Mediterranean and European trees is often fluctuating and controversial between the different major taxonomic works. We considered in priority the Euro+Med database (http://www.emplantbase.org/ home.html) and the Plant List database (https://www.theplantlist.org), but also the major national floras (see references in the "data sources" paragraph). In case of taxonomic-level disagreement, we retained the most consensual taxonomic level based also on recent phylogenetic studies or systematic revision of a given group, if available, adding consulting local experts or recent floras.

\section{Results}

\section{Mediterranean-European trees in a nutshell}

Our analysis of all the taxa that can potentially be tree species in the Mediterranean-European region provides a checklist of 245 tree taxa (i.e. species and subspecies), including 210 species and 35 subspecies (see Additional file 1).
These taxa belong to 33 different families; the most represented families are Rosaceae (42 taxa), Fagaceae (33 taxa), Pinaceae (21 taxa), Salicaceae (20 taxa), Sapindaceae (19 taxa), Betulaceae (16 taxa), Tamaricaceae (16 taxa), and Cupressaceae (14 taxa).

These tree taxa are included in 64 different genera which represents $86 \%$ of the total tree genera $(n=74)$ found in the whole Mediterranean biogeographic region (Quézel and Médail 2003). Four of these genera (Chamaerops, Phillyrea, Spartium, Tetraclinis) have their distribution centered in the Mediterranean region and can be considered as Mediterranean endemics sensu lato (at the biogeographical region level), whereas three taxa have a Tethysian origin (Ceratonia, Myrtus, Nerium) and occur in adjacent biogeographic regions as well. The other genera have larger distributions, in the Palearctic realm or beyond.

Among this checklist, 46 are endemic trees (30 species and 16 subspecies), i.e. mainly located within a single biogeographic province sensu Rivas-Martínez et al. (2004). This means that the rate of endemism is equal to $18.9 \%$ if we consider the species and subspecies levels, or $14.3 \%$ at the species level. The genera with the more endemic taxa are Quercus (6 taxa), Abies, Acer, and Pinus (4 taxa each), Alnus, Salix and Sorbus (3 taxa each). The presence of three narrow endemic species included in two relict genera (Liquidambar and Zelkova) and characteristic of the Cenozoic paleoflora distributed in the Palearctic realm should also be noted (Palamarev 1989).

Even though we only took into account taxa considered as indigenous to a given country or a biogeographical area, the native status of some tree species can sometimes be difficult to estimate, notably when they are frequently cultivated or used for afforestation, or when their center of origin or native range are still unclear (e.g. Castanea, Ceratonia, Ficus, Juglans, Olea: see discussion). Overall, it concerns 24 taxa (ca. $10 \%$ of the total checklist) that are widely cultivated or selected for afforestation purposed by forest services. The distribution of those native but locally domesticated Mediterranean tree taxa will be discussed in detail below since it represents a crucial issue for the conservation of local genetic resources.

This checklist also includes 44 unrecognized real trees or "cryptic trees", i.e. usually with a shrubby habit but which form a tree habit under certain environmental conditions (Table 1). These taxa belong to four main families (Rosaceae: 11 tree species, Cupressaceae: 5 tree species, Anacardiaceae and Fabaceae: 4 tree species each), and to two main genera (9 tree species in Crataegus and 5 in Juniperus). These cryptic trees represent the impressive and unexpected rate of $\approx 18 \%$ of the Mediterranean-European trees. 
Table 1 The 44 unrecognized real trees or "cryptic trees", i.e. usually with a shrubby form, occurring in the Mediterranean-European region, with indications about their distribution and ecology

\begin{tabular}{|c|c|c|c|}
\hline Taxa & Family & Global distribution area & Ecology \\
\hline Alnus viridis (Chaix) DC. & Betulaceae & Arctico-Alpine & Subalpine and oro-mediterranean scrublands \\
\hline Buxus balearica Lam. & Buxaceae & SW Mediterranean, S Anatolia & $\begin{array}{l}\text { Scrublands on predominantly carbonate } \\
\text { substrates }\end{array}$ \\
\hline Buxus sempervirens L. & Buxaceae & Mediterranean-European & Submediterranean scrublands \\
\hline Chamaerops humilis L. & Arecaceae & CW Mediterranean & $\begin{array}{l}\text { Thermophilous scrublands, coastal scree } \\
\text { and cliffs }\end{array}$ \\
\hline Cotinus coggygria Scop. & Anacardiaceae & S European, Irano-Turanian & $\begin{array}{l}\text { Eumediterranean and submediterranean } \\
\text { dry scrublands, warm and mesophilous } \\
\text { habitats of southern exposure inland }\end{array}$ \\
\hline Cotoneaster granatensis Boiss. & Rosaceae & Endemic to S Spain (Andalusia) & Rocky matorrals, deciduous and pine forests \\
\hline Crataegus azarolus L. & Rosaceae & E Mediterranean & Open scrublands \\
\hline Crataegus heldreichii Boiss. & Rosaceae & Balkan & $\begin{array}{l}\text { Open coniferous forests, mixed scrubs, dry } \\
\text { rocky meadows }\end{array}$ \\
\hline Crataegus laciniata Ucria & Rosaceae & CW Mediterranean & Clearings of mountain woods \\
\hline Crataegus laevigata (Poir.) DC. & Rosaceae & CW Mediterranean & $\begin{array}{l}\text { Mesophilic shingles and hedges of the hilly } \\
\text { and mountainous vegetation belt, oak forests } \\
\text { outside the flood, mountain beech forests }\end{array}$ \\
\hline Crataegus monogyna Jacq. & Rosaceae & Mediterranean-European & $\begin{array}{l}\text { Coastal dry scrublands, Inland mesophilic } \\
\text { shingles and hedges }\end{array}$ \\
\hline Crataegus nevadensis K.I.Chr. & Rosaceae & Endemic of S Spain (Andalusia) & Clearings and edges of mountain woods \\
\hline Crataegus orientalis Pall. ex M.Bieb. & Rosaceae & E Mediterranean and SW Asia & $\begin{array}{l}\text { Rocky places in meadows and open } \\
\text { woodlands }\end{array}$ \\
\hline Crataegus pentagyna Willd. & Rosaceae & Balkan & Open forest, mixed scrubs, dry rocky meadows \\
\hline Crataegus pycnoloba Boiss \& Heldr. & Rosaceae & Endemic of Greece (Peloponnese) & $\begin{array}{l}\text { Rocky limestone ridhes and slope, dry grassy } \\
\text { plateau, scrubs and open Abies cephalonica } \\
\text { forests }\end{array}$ \\
\hline Cytisus aeolicus Guss. & Fabaceae & Endemic of Sicily (Aeolian Islands) & $\begin{array}{l}\text { Dry slopes and open scrublands on volcanic } \\
\text { substrates }\end{array}$ \\
\hline Erica arborea L. & Ericaceae & $\begin{array}{l}\text { Mediterranean, Macaronesian, E. Africa, } \\
\text { Sahara }\end{array}$ & $\begin{array}{l}\text { Thermophilous scrublands in non-carbonatic } \\
\text { substrates }\end{array}$ \\
\hline Fontanesia philliraeoides Labill. & Oleaceae & E Mediterranean & Dry maquis \\
\hline Frangula alnus Mill. & Rhamnaceae & C European, Mediterranean & Riparian forests of alder and ash \\
\hline Genista etnensis (Raf.) DC. & Fabaceae & Endemic of Sicily, Sardinia and Corsica & $\begin{array}{l}\text { Arborescent matorrals on non-carbonatic } \\
\text { substrates }\end{array}$ \\
\hline Genista tyrrhena Valsecchi & Fabaceae & $\begin{array}{l}\text { Endemic of Sicily (Aeolian Islands) and } \\
\text { Lazio (Pontian Islands) }\end{array}$ & $\begin{array}{l}\text { Arid volcanic slopes on rocky and sandy } \\
\text { substrates }\end{array}$ \\
\hline Juniperus communis L. & Cupressaceae & Eurasiatic & $\begin{array}{l}\text { Rocky meadows, mountain pastures, } \\
\text { mesophilic hedges and shrubs, forests edges } \\
\text { in submontane areas }\end{array}$ \\
\hline Juniperus deltoides R.P.Adams & Cupressaceae & CE Mediterranean & Open woodlands and scrublands on mid-altitudes \\
\hline Juniperus navicularis Gand. & Cupressaceae & Endemic of SW Iberian Peninsula & Arborescent matorral on maritime sands \\
\hline Juniperus oxycedrus L. & Cupressaceae & Mediterranean-Pontic & $\begin{array}{l}\text { Eumediterranean and submediterranean dry } \\
\text { areas in open forests and matorrals }\end{array}$ \\
\hline Juniperus phoenicea L. & Cupressaceae & Mediterranean, Macaronesian, Red Sea & $\begin{array}{l}\text { Eumediterranean dry and warm areas in } \\
\text { evergreen oak and pine forests, coastal } \\
\text { matorrals }\end{array}$ \\
\hline Myrica faya Aiton & Myricaceae & Macaronesia, S Portugal & Underwood of pinewoods on siliceous \\
\hline Myrtus communis L. & Myrtaceae & $\begin{array}{l}\text { Mediterranean, Macaronesian, } \\
\text { Irano-Turanian }\end{array}$ & $\begin{array}{l}\text { Thermophilous scrublands on non-carbonatic } \\
\text { substrates, small swampy forest stands }\end{array}$ \\
\hline Nerium oleander L. & Apocynaceae & Mediterranean, Sahara & $\begin{array}{l}\text { Thermophilous and temporary riverbeds, wet } \\
\text { lowlands }\end{array}$ \\
\hline
\end{tabular}


Table 1 The 44 unrecognized real trees or "cryptic trees", i.e. usually with a shrubby form, occurring in the Mediterranean-European region, with indications about their distribution and ecology (Continued)

\begin{tabular}{|c|c|c|c|}
\hline Taxa & Family & Global distribution area & Ecology \\
\hline Phillyrea angustifolia L. & Oleaceae & W Mediterranean & $\begin{array}{l}\text { Evergreen oak and alepo pine forests, dry } \\
\text { and warm habitats often stony, matorrals }\end{array}$ \\
\hline Phillyrea latifolia L. & Oleaceae & Mediterranean & $\begin{array}{l}\text { Evergreen oak and alepo pine forests, on dry } \\
\text { and warm habitats often stony, matorrals }\end{array}$ \\
\hline Pistacia lentiscus L. & Anacardiaceae & Mediterranean, Macaronesian, & Evergreen oak forests and matorrals \\
\hline Pistacia terebinthus $\mathrm{L}$. & Anacardiaceae & Mediterranean, S European & Evergreen oak forests and matorrals \\
\hline Prunus mahaleb L. & Rosaceae & S European-Pontic & $\begin{array}{l}\text { Thermophilous forests of pubescent oak } \\
\text { and matorrals }\end{array}$ \\
\hline Quercus coccifera L. & Fagaceae & Mediterranean & Evergreen oak forests and matorrals \\
\hline Rhamnus alaternus $\mathrm{L}$. & Rhamnaceae & Mediterranean & $\begin{array}{l}\text { Mixed evergreen and deciduous forests, } \\
\text { matorrals dominated by evergreen oaks }\end{array}$ \\
\hline Rhododendron ponticum L. & Ericaceae & $\begin{array}{l}\text { S Iberian Peninsula, Lebanon, } \\
\text { Pontic region }\end{array}$ & $\begin{array}{l}\text { Mixed woodlands in humid ravines on } \\
\text { siliceous }\end{array}$ \\
\hline Sambucus nigra L. & Adoxaceae & European-Caucasian & $\begin{array}{l}\text { Mesophilous underbrushs and hedges in } \\
\text { hilly and mountains areas, deciduous forests }\end{array}$ \\
\hline Searsia tripartita (Ucria) Moffett & Anacardiaceae & S Mediterranean, Sahara & $\begin{array}{l}\text { Open rocky matorrals in arid and desertic } \\
\text { areas, temporary river banks }\end{array}$ \\
\hline Spartium junceum L. & Fabaceae & Mediterranean, European & $\begin{array}{l}\text { Eumediterranean dry, warm and stony areas, } \\
\text { often in more or less pure stands }\end{array}$ \\
\hline Styrax officinalis L. & Styracaceae & CE Mediterranean & $\begin{array}{l}\text { Rocky and dry grasslands, thermophilous } \\
\text { matorrals with evergreen oaks and alepo } \\
\text { pine }\end{array}$ \\
\hline Vitex agnus-castus L. & Lamiaceae & Mediterranean, Irano-Turanian & $\begin{array}{l}\text { Riverbeds, wet lowlands, thermophilous } \\
\text { damp or floodes underbrushes }\end{array}$ \\
\hline Zelkova abelicea (Lam.) Boiss. & Ulmaceae & Endemic of Crete & $\begin{array}{l}\text { Rocky slopes or flat valley bottoms in the } \\
\text { mountains }\end{array}$ \\
\hline $\begin{array}{l}\text { Zelkova sicula Di Pasquale, } \\
\text { Garfi \& Quézel }\end{array}$ & Ulmaceae & Endemic of Sicily & Scrublands on basaltic soil, riverbeds \\
\hline
\end{tabular}

\section{Mediterranean-European tree diversity by administrative regions}

Mapping the presence of tree species in each Mediterranean-European country is important to estimate conservation priorities at the administrative level. Our analysis shows that the countries (continental parts) with the highest total richness of native trees (> 110 taxa) are Greece (146 taxa), Italy (133 taxa), Albania (122 taxa), Spain (115 taxa), Macedonia (116 taxa), and Croatia (110 taxa) (Fig. 1a, Table 2). There is a strong disparity in total richness between the large Mediterranean islands: Sicily has the highest richness (88 taxa), and the Balearic Islands the lowest one (35 taxa), whereas Corsica and Sardinia in the western Mediterranean Basin exhibit a similar richness (respectively 70 and 76 taxa) and Cyprus and Crete in the eastern basin share quite similar level of tree richness (respectively 42 and 52 taxa).

While the total tree richness is concentrated mainly in the Balkans, endemic trees mostly occurred in the large countries of the three peninsula in western, central and eastern Mediterranean area (Table 2). Greece (11 endemic taxa), Spain (9 endemic taxa), and Italy (7 endemic taxa) exhibited the highest number of endemic taxa. Emphasis should be given to the place of some large Tyrrhenian islands that shelter a significant number of endemic trees (Sicily: 10 taxa, Sardinia: 7 taxa).

The species-area relationships show contrasting results between administrative regions and large Mediterranean islands (Fig. 2). The relationship is significant for the islands ( $\log$ richness islands: $-1.89841+0.25788$ $\log$ surface islands, $p=0.01)$ but not for the continental areas of the countries (log richness continents: 3.8459 $+0.03493 \log$ surface continents, $p=0.41)$. The continental areas of the central and eastern Mediterranean countries, from Italy to Greece (i.e. mainly the Balkans), have a significantly higher tree taxonomic richness than those located further west or on the large islands. Thus, the islands always have a lower richness per unit area than continents. This is particularly the case for Malta and the Balearic Islands. Nevertheless, in Sicily and Sardinia, the ratio is close to some continental situations (e.g. France, Slovenia) and is even higher that Portugal which shows the lowest area-species ratio for a continental country. 
Table 2 Number of total native tree taxa (including endemic and putative native taxa), endemic tree taxa, and putative native tree taxa) by administrative areas and main islands of the Mediterranean-European region. "Taxa" include both species and sub-species level

\begin{tabular}{lllll}
\hline Countries & $\begin{array}{l}\text { Total native } \\
\text { taxa richness }\end{array}$ & $\begin{array}{l}\text { Endemic taxa } \\
\text { richness }\end{array}$ & $\begin{array}{l}\text { Putative native } \\
\text { taxa richness }\end{array}$ & $\begin{array}{l}\text { Presence } \\
\text { uncertainty }\end{array}$ \\
\hline Albania & 122 & 2 & 3 & 0 \\
Balearic & 33 & 1 & 0 & 0 \\
Corsica & 70 & 5 & 0 & 0 \\
Crete & 52 & 4 & 0 & 0 \\
Croatia & 110 & 2 & 0 & 0 \\
Cyprus & 42 & 3 & 0 & 0 \\
France & 102 & 1 & 3 & 0 \\
Greece & 146 & 11 & 0 & 0 \\
Italy & 133 & 7 & 0 & 0 \\
Macedonia & 116 & 3 & 3 & 2 \\
Malta & 25 & 0 & 5 & 0 \\
Montenegro & 108 & 1 & 0 & 1 \\
Portugal & 69 & 3 & 3 & 0 \\
Sardinia & 76 & 7 & 0 & 0 \\
Sicily & 88 & 10 & 0 & 0 \\
Slovenia & 85 & 0 & 1 & 0 \\
Spain & 115 & 9 & 0 & 0 \\
\hline
\end{tabular}

\section{Mediterranean-European tree diversity by biogeographical areas}

To go beyond their distribution in the administrative regions, we extracted the number of native tree taxa (species and subspecies) for each of the 13 biogeographic provinces sensu Rivas-Martínez et al. (2004) (Fig. 3a). The raw numbers of tree richness are culminating in the central-eastern provinces of the Mediterranean-European region: Apennino-Balkan (142 taxa), Graeco-Aegean (137 taxa), Adriatic (135), and Italo-Tyrrhenian (128 taxa). The lowest richness (40 taxa) is found in the Cilicio-Phoenician province which corresponds only (in our study area) to the island of Cyprus (Fig. 3b). The highest taxonomic richness in endemic trees occurs in the Italo-Tyrrhenian ( $n=16$ taxa) and in the Graeco-Aegean $(n=12$ taxa) provinces, then in the Betican $(n=9$ taxa) and Adriatic ( $n=8$ taxa) provinces (Fig. 3c). The lowest endemic richness $(n=1$ taxa) is found in southern France, and in the southern parts of the Alpine and Cevenno-Pyrenean provinces.

The species-area relationship for biogeographic provinces clearly discriminated the central-eastern (mainly Balkans) and northern (Alpine and Cevenno-Pyrenean) provinces, against the five western provinces in the Iberian Peninsula (Fig. 4).

\section{Threatened trees}

Among the 245 tree taxa of the checklist, 15 constitute threatened taxa sensu IUCN (2 CR, 7 EN, $6 \mathrm{VU}$ ) and 4 are classified as near threatened taxa (NT) (Table 3). Only 154 tree taxa (145 species and 9 subspecies) are classified as "least concern" (LC), and 23 species with data gap for assessment (DD). What is most worrying is that 84 taxa (19 species and 65 subspecies) included in the checklist are not considered at all in the global IUCN assessment. Eleven of these threatened tree taxa, including some very narrow endemic trees such as Abies nebrodensis, Cytisus aeolicus, Rhamnus persicifolia, Zelkova abelicea and Zelkova sicula are only distributed on some large (notably Sicily, Crete, Cyprus and Sardinia) or medium (few Croatian islands sheltering Pinus nigra subsp. dalmatica populations) sized islands of the Mediterranean Sea.

\section{Discussion \\ Distribution of tree diversity in the Mediterranean- European region}

Our comprehensive analysis of tree taxonomic diversity in the Mediterranean-European region identified 210 tree species or 245 species and subspecies, including 46 endemic trees of the study area. This is of course a tiny portion of the estimated tree diversity worldwide (ca. 60,065 tree species currently known to science, see Beech et al. 2017), but an important number regarding to the European forests. Tree taxonomic diversity was estimated at 135 species and subspecies within the medio-European region (Quézel and Médail 2003), whereas only 42 tree species from 11 families occur in Central Europe (Leuschner and Meier 2018). It represents also of high tree diversity compared to the one in the entire Mediterranean biogeographical region which was estimated at 290 species and subspecies (Quézel and Médail 2003), i.e. 85\% of the trees of the whole Mediterranean region occur in the European part. This key result shows the importance of the southern part of Europe in preserving this rich biological heritage for a temperate region.

The taxonomic richness of the Mediterranean-European region is also found in tree genera, since $86 \%$ of the total genera $(n=74)$ of the whole Mediterranean biogeographic region are present in this European part. Only 11 genera (Acacia, Amygdalus, Argania, Balanites, Calotropis, Diospyros, Dracaena, Moringa, Prospis, Pterocarya, Ziziphus) are restricted to the southern or eastern parts of the Mediterranean region.

These results are not surprising since Mediterranean forests are very diverse and heterogeneous regarding their structure, their specific composition and their dynamics (Quézel and Médail 2003), and this explains the existence of 35 terrestrial sub-ecoregions including 


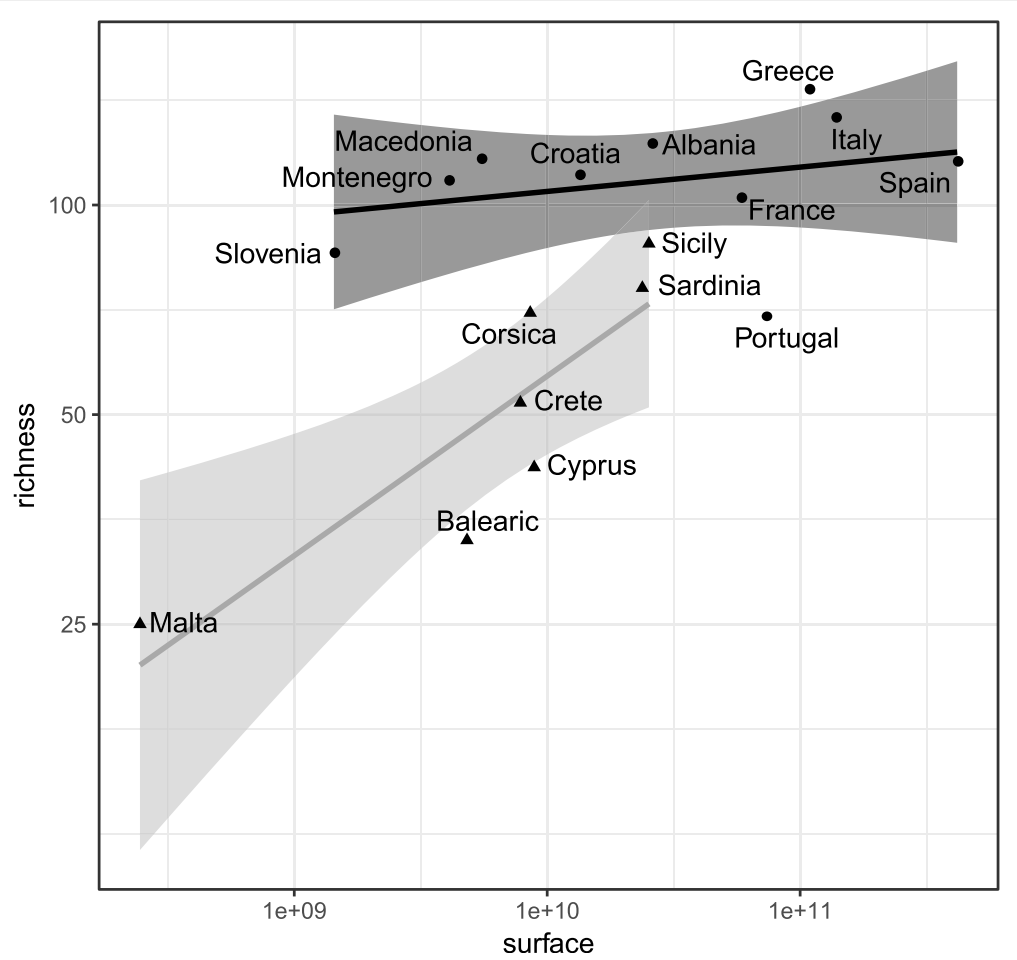

Fig. 2 Linear regressions between the total native tree taxa richness and the surface of continental administrative areas (black regression line and black circles) or main islands (grey regression line and black triangles) in the Mediterranean-European region with their respective $95 \%$ confidence interval. Abscissa and ordinate axes have a logarithmic scale. Dots above each line indicate higher richness than predicted by the species-area relationship, and dots below each line indicate lower richness than expected

forests (WWF 2001). The main forest types are: (i) sclerophyllous forests (notably with the oaks Quercus ilex, Q. suber, Q. coccifera); (ii) dry conifer (Pinus halepensis, P. brutia) forests; (iii) deciduous mixed forests with broad-leaved oaks (Quercus pubescens, Q. faginea, Q. ithaburensis) and other genera (Acer, Carpinus, Fraxinus, Sorbus); (iv) mountain conifer forests with Abies, Cedrus, Juniperus, Pinus nigra. Tree diversity and the ecological complexity in forest types can be explained both by the complex paleogeography and historical biogeography of the Mediterranean region, and also by the high heterogeneity in the climate (Médail 2008; Blondel et al. 2010).

This woody biodiversity is unevenly distributed within the Mediterranean-European region. Our analysis, performed either at the administrative or biogeographic level, indicate that the continental areas of the central and eastern Mediterranean countries, from Italy to Greece (i.e. mainly the Balkans), have a significantly higher tree richness compared to those located further west (Iberian Peninsula) or on large Mediterranean islands. The higher taxonomic diversity in the eastern Mediterranean Basin is found in several other studies and this pattern is probably related to the key biogeographical crossroad of this area and to the existence of more suitable conditions during the LGM (notably warmer summer temperatures) inducing larger biodiversity refugia (Médail and Diadema 2009; Fady and Conord 2010). Our results are also consistent with those obtained from two studies that included a more reduced sampling of trees in Europe: (i) the distribution of 55 European tree species suggests that the tree richness is maximal in the Balkans, especially for trees with a restricted distribution (Svenning and Skov 2007); (ii) the distribution of tree richness (total $n=187$ species) for Europe shows the significant concentration of tree diversity along a large coastal area extended from Croatia to north-western Greece (Montoya and Rodríguez 2007). Both studies concluded that the main driver of the variation of tree richness is the current climate, and that the climate during the Last Glacial Maximum (LGM, ca. $20 \mathrm{ky}$ ago) or the period since an area became free of ice have a significant influence, notably to explain the concentration of range-restricted tree taxa. Some studies also revealed that older climatic events throughout the Miocene were also critical for extinction in the western part of the Mediterranean Basin (the Iberian Peninsula) and may partly explain the relative lower richness of tree taxa there (Postigo Mijarra et al. 2009). The species-area relationships indicate that Mediterranean islands always have a lower richness per unit area, and only the two largest islands, Sicily and Sardinia, are grouped with the continental territories of higher tree 

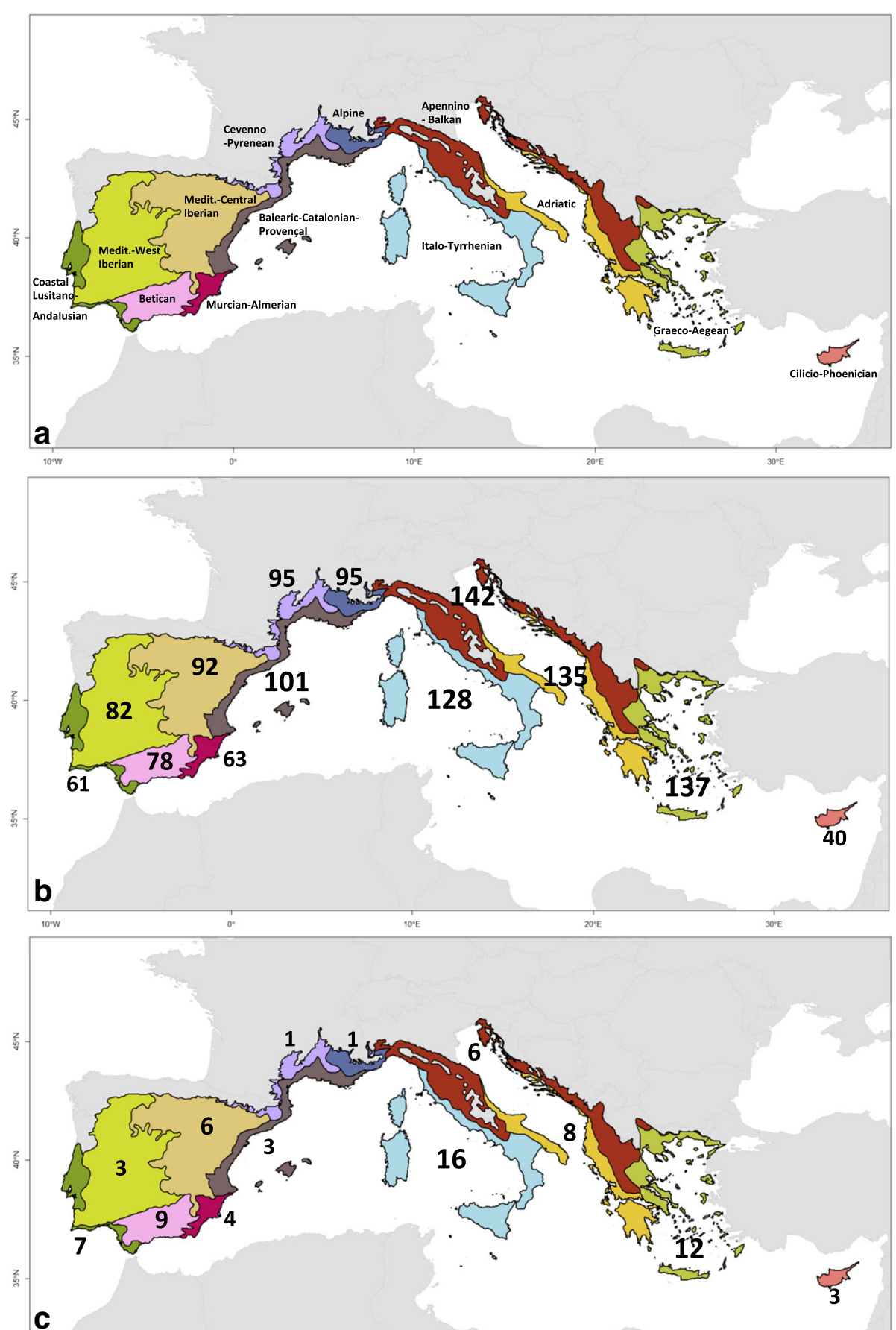

Fig. 3 a Distribution of the 13 biogeographical provinces sensu Rivas-Martínez et al. (2004) in the study area; b Number of native tree taxa (species and subspecies) and (c) Number of endemic tree taxa (species and subspecies) in each biogeographical province

richness. For Sicily, this pattern can also be explained by the proximity of this large continental island to the Italian Peninsula and its connection to the mainland during the LGM which facilitated the putative latitudinal migration of trees.

The distribution of the native or endemic tree taxa richness by biogeographical provinces sensu Rivas-Martínez et al. (2004) shows congruent results. Taxonomic richness is highest in the central-eastern Mediterranean provinces, notably: (i) in the Graeco-Aegean and the Italo-Tyrrhenian provinces for both native and endemic taxa, (ii) in the Apennino-Balkan and Adriatic provinces for native tree richness only. By contrast, in the western Mediterranean, only the Betican Province is noteworthy for its endemic tree 


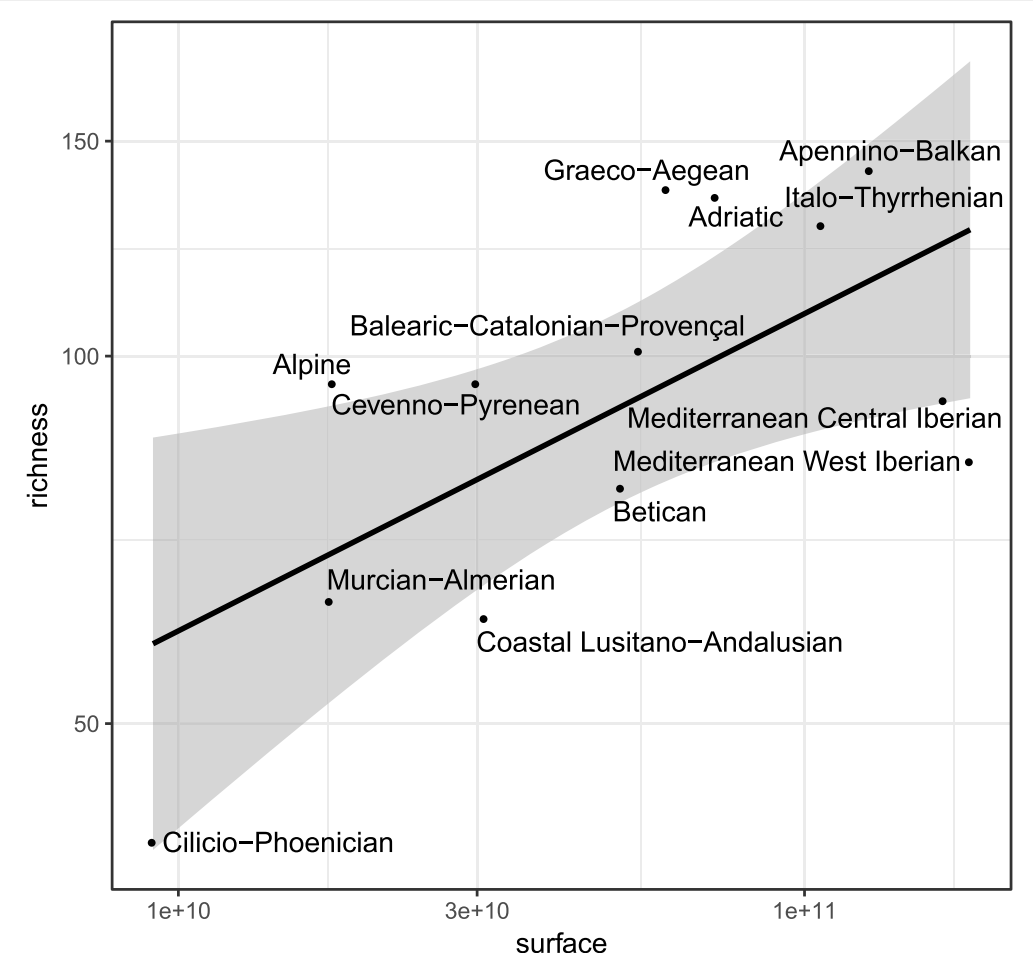

Fig. 4 Linear regression between the total native tree richness and the surface of each of the 13 biogeographic provinces sensu Rivas-Martínez et al. (2004). Abscissa and ordinate axes have a logarithmic scale. Shade area represents the $95 \%$ confidence interval around the predictions. Dots above the line indicate higher richness than predicted by the species-area relationship, and dots below the line indicate lower richness than expected

richness, since this area represents a hotspot for the differentiation of the endemic flora through geographical isolation and/or repeated specialization to contrasted environments (Molina-Venegas et al. 2015).

Of course, this assessment ultimately depends on the taxonomic conceptions used, which can vary very significantly depending on the published sources. We retained a rather restrictive approach and not consider trees with uncertain taxonomic status as Bartolucci et al. (2018) did for instance in the recent Updated checklist of the vascular flora native to Italy; for the only island of Sicily, 11 tree taxa could be included (Betula aetnensis, Fraxinus excelsior subsp. sicilienesis, Malus crescimannoi, Pyrus castribonensis, Pyrus ciancioi, Pyrus sicanorum, Pyrus vallis-demonis, Rhamnus lojaconoi, Salix nebrodensis, Sorbus madoniensis, Sorbus busambarensis), but more precise taxonomic studies are hardly needed.

\section{What is a Mediterranean tree?}

In this study, we defined as tree a species with a height that can potentially reach $3 \mathrm{~m}$, with a single stem and an arborescent habit (i.e. with a well individualized crown). This corresponds mainly to the definition of phanerophytes in the Raunkiær system for categorizing life forms (Raunkiær 1934). Therefore, several woody taxa of the Mediterranean matorrals were excluded (e.g. Amelanchier ovalis, Anthyllis barba-jovis, Viburnum tinus), even if they can exceed $3 \mathrm{~m}$ high. On the contrary, the only two monocot species, the Mediterranean palms Chamaerops humilis and Phoenix theophrasti, with a solitary or multiple trunks, were included in our checklist even if they do not form a real trunk (but a stipe) from an anatomical point of view. Our definition is quite similar, but more restrictive, to that of the IUCN's Global Tree Specialist Group: "a woody plant with usually a single stem growing to a height of at least two meters, or if multi-stemmed, then at least one vertical stem five centimeters in diameter at breast height" (Beech et al. 2017).

However, while our tree definition is more conservative than that of the GTS database, our analysis highlights the absence of 22 tree taxa in this latter (Table 4). Assessing if a taxon could sometimes have the habits of a tree or if it is always a shrub was one of the biggest difficulties during the elaboration of the checklist. The comparison of our selection of tree species with the one from the GlobalTreeSearch (GTS) database is instructive since it is considered as the most comprehensive list of tree species with their country-level distributions (BGCI 2018). The missing taxa correspond for almost half $(n=10)$ to species that possess a shrub habit in general but can form trees in certain geographical situations (e.g. Spartium junceum in the Aeolian Islands, Italy) or ecological conditions 
Table 3 Threatened tree taxa sensu IUCN Red List categories (CR, EN, VU, NT) (IUCN 2018) occurring in the Mediterranean-European region (in brackets the distribution outside the study area)

\begin{tabular}{|c|c|c|c|c|c|c|c|}
\hline Threatened tree taxa & $\begin{array}{l}\text { RedList } \\
\text { status }\end{array}$ & $\begin{array}{l}\text { RedList } \\
\text { criteria }\end{array}$ & $\begin{array}{l}\text { RedList } \\
\text { version }\end{array}$ & $\begin{array}{l}\text { Year } \\
\text { published }\end{array}$ & $\begin{array}{l}\text { Global populations' } \\
\text { trends (IUCN) }\end{array}$ & Distribution & $\begin{array}{l}\text { Comments related to the } \\
\text { study area }\end{array}$ \\
\hline Abies nebrodensis & $C R$ & $\mathrm{~A} 2 \mathrm{~cd}$ & 3,1 & 2017 & increasing & Sicily & $\begin{array}{l}\text { Very narrow endemic } \\
\text { to Sicily; } 32 \text { adult trees } \\
\text { in the unique natural } \\
\text { population }\end{array}$ \\
\hline Zelkova sicula & $C R$ & B1ab(iii) + 2ab(iii) & 3,1 & 2017 & stable & Sicily & $\begin{array}{l}\text { Narrow endemic of SE } \\
\text { Sicily (Mts. Iblei) }\end{array}$ \\
\hline Abies pinsapo & EN & B1ab(iii) + 2ab(iii) & 3,1 & 2018 & stable & Spain & $\begin{array}{l}\text { Narrow distribution in } \\
\text { S. Spain (Andalusia), in } \\
\text { three isolated ranges } \\
\text { included in protected } \\
\text { areas }\end{array}$ \\
\hline $\begin{array}{l}\text { Betula pendula subsp. } \\
\text { fontqueri }\end{array}$ & EN & $\mathrm{B} 1+2 \mathrm{ac}$ & 2.3 & 1998 & & Spain (Morocco) & $\begin{array}{l}\text { Present in Central and } \\
\text { South Spain and, outside } \\
\text { the study are, a very } \\
\text { narrow range in N. } \\
\text { Morocco (Rif mountains) }\end{array}$ \\
\hline Cytisus aeolicus & EN & B1ab(iii,v) + 2ab(iii,v) & 3,1 & 2017 & decreasing & Sicily & $\begin{array}{l}\text { Narrow endemic to Sicily, } \\
\text { on the Aeolian islands of } \\
\text { Vulcano, Stromboli and } \\
\text { Alicudi }\end{array}$ \\
\hline Liquidambar orientalis & EN & $\mathrm{A} 2 \mathrm{C}$ & 3,1 & 2018 & stable & Greece (Turkey) & $\begin{array}{l}\text { Tertiary relict restricted } \\
\text { to a small valley in } \\
\text { Rhodos }\end{array}$ \\
\hline $\begin{array}{l}\text { Pinus nigra subsp. } \\
\text { dalmatica }\end{array}$ & EN & B1ab(iii,v) + 2ab(iii,v) & 3,1 & 2013 & decreasing & Croatia & $\begin{array}{l}\text { Narrow endemic of } \\
\text { Pelješac penninsula } \\
\text { and some islands } \\
\text { (Brac, Hvar and Korcula) } \\
\text { of the Adriatic Sea }\end{array}$ \\
\hline Rhamnus persicifolia & EN & B1ab(iii,v) + 2ab(iii,v) & 3,1 & 2017 & decreasing & Sardinia & $\begin{array}{l}\text { Narrow endemic of CE } \\
\text { Sardinia (Gennargentu } \\
\text { and Supramonte massifs) }\end{array}$ \\
\hline Zelkova abelicea & EN & B1ab(iii) + 2ab(iii) & 3,1 & 2012 & decreasing & Crete & Narrow endemic of Crete \\
\hline $\begin{array}{l}\text { Aesculus } \\
\text { hippocastanum }\end{array}$ & VU & $\mathrm{C} 2 \mathrm{a}(\mathrm{i})$ & 3,1 & 2017 & decreasing & $\begin{array}{l}\text { Albania, Greece, } \\
\text { Macedonia (Bulgaria) }\end{array}$ & $\begin{array}{l}\text { A Tertiary relict on the } \\
\text { Balkan Peninsula, with } \\
\text { main occurrence in } \\
\text { Greece; present in } \\
\text { two protected areas } \\
\text { in Macedonia: the } \\
\text { National Park Mavrovo } \\
\text { and Galichica }\end{array}$ \\
\hline $\begin{array}{l}\text { Cedrus libani subsp. } \\
\text { brevifolia }\end{array}$ & VU & B2ab(ii,iii,v) & 3,1 & 2013 & decreasing & Cyprus & $\begin{array}{l}\text { Endemic to Cyprus; } \\
\text { restricted to a small } \\
\text { area in Pafos forest } \\
(900-1400 \mathrm{~m})\end{array}$ \\
\hline $\begin{array}{l}\text { Prunus lusitanica } \\
\text { subsp. Iusitanica }\end{array}$ & $\mathrm{VU}$ & B2ab(ii,v) & 3,1 & 2011 & decreasing & $\begin{array}{l}\text { Portugal, Spain } \\
\text { (SW. France) }\end{array}$ & $\begin{array}{l}\text { Populations in isolated } \\
\text { ranges in } C \text { and } N \\
\text { Portugal an C and N } \\
\text { Spain; outside the } \\
\text { study area, there are } \\
\text { small populations in } \\
\text { Morocco (W. Rif and } \\
\text { Middle Atlas) }\end{array}$ \\
\hline Salix xanthicola & VU & B1ab(iii,v) + 2ab(iii,v) & 3,1 & 2017 & decreasing & Greece (Bulgaria) & $\begin{array}{l}\text { Endemic to the Balkan } \\
\text { Peninsula occurring } \\
\text { only in NE Greece and } \\
\text { Bulgaria; distribution area } \\
\text { fairly small and restricted } \\
\text { to western Thrace of the } \\
\text { Balkan Peninsula }\end{array}$ \\
\hline
\end{tabular}


Table 3 Threatened tree taxa sensu IUCN Red List categories (CR, EN, VU, NT) (IUCN 2018) occurring in the Mediterranean-European region (in brackets the distribution outside the study area) (Continued)

\begin{tabular}{|c|c|c|c|c|c|c|c|}
\hline Threatened tree taxa & $\begin{array}{l}\text { RedList } \\
\text { status }\end{array}$ & $\begin{array}{l}\text { RedList } \\
\text { criteria }\end{array}$ & $\begin{array}{l}\text { RedList } \\
\text { version }\end{array}$ & $\begin{array}{l}\text { Year } \\
\text { published }\end{array}$ & $\begin{array}{l}\text { Global populations' } \\
\text { trends (IUCN) }\end{array}$ & Distribution & $\begin{array}{l}\text { Comments related to the } \\
\text { study area }\end{array}$ \\
\hline Searsia tripartita & $\mathrm{VU}$ & D1 & 3,1 & 2017 & unknown & Sicily & $\begin{array}{l}\text { Restricted in the SE } \\
\text { part of Sicily, perhaps } \\
\text { introduced during the } \\
\text { Antiquity }\end{array}$ \\
\hline Sorbus latifolia & $\mathrm{VU}$ & B1ab(iii) & 3,1 & 2017 & stable & $\begin{array}{l}\text { Portugal, Spain, } \\
\text { (France) }\end{array}$ & $\begin{array}{l}\text { Present in C Portugal } \\
\text { and isolated ranges in } \\
\mathrm{C} \text { and NE Spain; species } \\
\text { of hybrid origin, with } \\
\text { rare sexual reproduction. }\end{array}$ \\
\hline Tamarix boveana & VU & B2ab(iii,iv,v) & 3,1 & 2018 & decreasing & $\begin{array}{l}\text { Balearic Is., E Spain } \\
\text { (North Africa) }\end{array}$ & $\begin{array}{l}\text { Small and isolated } \\
\text { populations }\end{array}$ \\
\hline Fraxinus excelsior & NT & & 3,1 & 2018 & decreasing & $\begin{array}{l}\text { Albania, Croatia, } \\
\text { France, Greece, Italy, } \\
\text { Macedonia, Montenegro, } \\
\text { Sicily, Slovenia, Spain } \\
\text { (Europe) }\end{array}$ & $\begin{array}{l}\text { A medio-European } \\
\text { tree, quite common } \\
\text { in the northern limit } \\
\text { of the Mediterranean } \\
\text { region (sub-Mediterranean } \\
\text { transition zone) }\end{array}$ \\
\hline Pistacia atlantica & NT & & 3,1 & 2018 & decreasing & $\begin{array}{l}\text { Cyprus, Greece (North } \\
\text { Africa, Middle East) }\end{array}$ & $\begin{array}{l}\text { Widespread in the } \\
\text { Mediterranean area and } \\
\text { SW Asia; only of regional } \\
\text { occurrence in Greece and } \\
\text { scattered in Cyprus }\end{array}$ \\
\hline Phoenix theophrasti & NT & & 2,3 & 1998 & decreasing & Cyprus, Greece (Turkey) & $\begin{array}{l}\text { East-Mediterranean } \\
\text { element with its main } \\
\text { populations on the } \\
\text { island of Crete; some } \\
\text { additional small stands } \\
\text { occur elsewhere in the } \\
\text { S Aegean area and in } \\
\text { the Datça Peninsula of } \\
\text { SW Anatolia }\end{array}$ \\
\hline Quercus aucheri & NT & & 2,3 & 1998 & & Greece (Turkey) & $\begin{array}{l}\text { East-Mediterranean } \\
\text { element occurring to } \\
\text { a relatively small area } \\
\text { in the East Aegean } \\
\text { Islands and SW Anatolia }\end{array}$ \\
\hline
\end{tabular}

(e.g. Buxus balearica, Crataegus laciniata, Nerium oleander, Phillyrea angustifolia, Rhododendron ponticum). Some other missing taxa are related to recently described species (e.g. Alnus lusitanica and A. rohleana, see Vit et al. 2017), or to different taxonomic conceptions (e.g. Abies borisii-regis or Quercus gussonei considered or not as a hybrids).

Thus, our precise assessment of the expression of the potential arboreal character of the woody species located in the Mediterranean-European region (based on the literature data and on many in situ novel observations) allows us to identify 44 unrecognized real trees, or "cryptic trees", representing $21 \%$ of the total trees occurring in this area (Table 1). This result constitutes an important issue to better understand the links between shrub vs. tree habit in relation to current and future climatic conditions (Olson et al. 2018), but also to past and current human impacts which are very important in the Mediterranean region for several millennia (Thirgood
1981). With increasing drought and warming, trees worldwide experience mortality or dieback and it is important to understand how plant height relates to climate. A recent meta-analysis suggests that plant height is linked to climate via plant hydraulics which explains why vegetation height differs across biomes and is altered with climate change (Olson et al. 2018). In the Mediterranean region, due to millenia-long human impact, we consider that the ecophysiological expression of the tree habit has been often inhibited in most of ecological situations, in parallel with the increase of climate drought. The very arid conditions that many Mediterranean ecosystems experience implies severe constraints on tree architecture and growing. This is the case of the trees belonging to the mesophilous relict genus Zelkova (Ulmaceae): the dwarfed Zelkova abelicea trees (a narrow Cretan endemic) can attain ages >500 yr. and these individuals survive under high browsing pressure for centuries, surpassing normally growing trees 
Table 4 The 22 tree taxa occurring in the Mediterranean-European region but not considered in the GlobalTreeSearch database (http:// www.bgci.org/global_tree_search.php?action=about; see also Beech et al. 2017)

\begin{tabular}{|c|c|c|}
\hline Tree taxa & Family & Potential explanation \\
\hline Abies borisii-regis & Pinaceae & Taxonomy \\
\hline Alnus lusitanica & Betulaceae & Recent description \\
\hline Alnus rohlenae & Betulaceae & Recent description \\
\hline Buxus balearica & Buxaceae & Shrub \\
\hline Cotoneaster granatensis & Rosaceae & Shrub \\
\hline Crataegus laciniata & Rosaceae & Shrub \\
\hline Crataegus nevadensis & Rosaceae & Shrub \\
\hline Fontanesia philliraeoides & Oleaceae & Shrub \\
\hline Juniperus deltoides & Cupressaceae & Recent description \\
\hline Juniperus navicularis & Cupressaceae & Taxonomy \\
\hline Myrica faya & Myricaceae & Shrub \\
\hline Nerium oleander & Apocynaceae & Shrub \\
\hline Phillyrea angustifolia & Oleaceae & Shrub \\
\hline Pyrus pyraster & Rosaceae & Shrub \\
\hline Quercus gussonei & Fagaceae & Taxonomy \\
\hline Rhododendron ponticum & Ericaceae & Shrub \\
\hline Salix amplexicaulis & Salicaceae & Shrub \\
\hline Salix apennina & Salicaceae & Shrub \\
\hline Salix arrigonii & Salicaceae & Knowledge gap \\
\hline Salix fragilis & Salicaceae & Shrub \\
\hline Salix xanthicola & Salicaceae & Shrub \\
\hline Spartium junceum & Fabaceae & Shrub \\
\hline
\end{tabular}

of the same population in number and age (Fazan et al. 2012).

While some cryptic trees are narrow endemics (e.g. Cytisus aeolicus and Genista tyrrhena from the Aeolian archipelago in Sicily), most of them are widespread taxa (e.g. Chamaerops humilis, Erica arborea, Myrtus communis, Juniperus oxycedrus, Pistacia lentiscus, Phillyrea latifolia, Prunus mahaleb) that form the keystone species of most of the matorrals (Quézel and Médail 2003). For example, under some constant humid and thermophilous conditions of a coastal marsh, a real forest dominated by impressive Myrtus communis (Myrtaceae) and Phillyrea latifolia (Oleaceae) trees has been recently described in southern Corsica Island (CBN Corse, ined.). Some other cryptic trees are much rarer, and their discoveries were surprising. This is the case of a 12-m high individual of Cotinus coggygria (Anacardiaceae), with a trunk circumference of $60 \mathrm{~cm}$, found in a Montenegro forest (F. Médail and A.-C. Monnet, ined., VI.2018).

An interesting evolutionary question would be to analyze more finely whether the insular conditions also favor the expression of the arborescent habit for these trees of the Mediterranean islands, an insular syndrome already demonstrated for various endemic groups on some remote oceanic islands, due to speciation by cladogenesis (adaptive radiation, e.g. Lens et al. 2013). The remarkable lability in growth forms between herbaceous and woody habits in these insular situations suggest that the transition from a bush habit to a tree habit is an easier step. But it remains a neglected and overlooked process, even if it must have played a quite significant role in the dynamics and adaptive response of woody plants within a high-stress biome such as the Mediterranean region. Another alternative explanation could be related to better refuge conditions in some situations: unusual big trees or cryptic trees would represent in some Mediterranean areas, notably islands, the remains of old forests in lesser harsh and more stable climates.

\section{The complex native status of domesticated or useful Mediterranean trees}

Since the Neolithic, human pressures on Mediterranean ecosystems, especially on the forests, have been intense and the profound transformations of natural into cultural landscapes are the result of millennia of human activities (Thirgood 1981; Quézel and Médail 2003; Blondel 2006). With the exploitation of resources provided by tree species, humans interfered with their natural distribution. These useful plants have been gathered or cultivated since ancient times and some of them (e.g. olive, walnut and chestnut trees) are even used as biomarkers for estimating the beginnings of anthropization of a given Mediterranean area (e.g. Mercuri et al. 2013; Ucchesu et al. 2015). This explains why it is often difficult, and to some extent controversial, to estimate the native status of domesticated Mediterranean trees to a given country or a biogeographical area, especially because the putative sympatric presence of wild specimens and of cultivated varieties in a same locality.

Among the 24 trees that are widely cultivated or selected in afforestation by forest services in the MediterraneanEuropean region, the origin of several of them has been particularly discussed by biogeographers. But some recent phylogeographical and/or paleoecological studies provide sometimes counterintuitive results. For some sclerophyllous species (the laurel tree Laurus nobilis: Rodríguez-Sánchez et al. 2009; Marino et al. 2014; the myrtle, Myrtus communis: Migliore et al. 2012) that are not domesticated but only used by humans, the classical hypothesis of an eastern Mediterranean origin followed by subsequent westward expansion and diversification across the western Mediterranean and Macaronesia is verified. These cases suggest here a limited influence of historical human-mediated translocations despite the ancient use of these species. But for other widely domesticated 
Mediterranean trees, such an east-west vicariance across the Mediterranean region is not applicable. The biogeography and domestication of the olive tree (Olea europaea), the most iconic Mediterranean tree, are well documented (e.g. Besnard and Rubio de Casas 2016). Four large areas of persistence (macro-refugia) of oleaster populations occurred during the Last Glacial Maximum (LGM), with probable isolated micro-refugia in the central Mediterranean Basin; then, came the post-glacial diffusion of oleaster throughout the Mediterranean Basin facilitated by human intervention, but a single primary domestication of the olive seems to have occurred in the eastern Mediterranean. Similar global patterns of persistence into multiple peri-Mediterranean refugia followed by post-glacial migrations that preceded domestication seem to apply to other domesticated trees such as the common fig, Ficus carica (Khadari et al. 2005) and the carob tree, Ceratonia siliqua (Baumel et al. 2018). This challenges the classical hypothesis of an exclusive eastern Mediterranean origin and then a westward colonization for these important fruit tree species.

The difficulty of estimating the native distribution arises also in other cultivated medio-European trees that are not only present in the Mediterranean region. It exists indeed conflicting results between an ecological niche model projecting a significant presence of walnut (Juglans regia) in the Balkan Peninsula during the LGM in contrast to genetic analysis that suggest refugia in Southwest Asia (Aradhya et al. 2017). For another key cultivated tree, the chestnut (Castanea sativa), a paleodistribution modelling approach validated with pollen and charcoal records (Roces-Díaz et al. 2018) seems to be in agreement with a phylogeographical analysis (Mattioni et al. 2013): LGM refugia were suggested in the north of the Iberian and Italian peninsulas, in Greece, and along the southern coast of the Black Sea. But if the hypothesis of chestnut migration from Turkey and Greece to Italy and Spain is clearly rejected, the authors cannot conclude whether "the populations from Italy and Spain could have originated from common refugia in western Europe or could have resulted from human-mediated transplanting of materials or both" (Mattioni et al. 2013)! These uncertainties are also linked to genetic sampling that is too incomplete with respect to the current distribution area of chestnut, with unfortunately the same shadow areas in the Mediterranean region (Northwest Balkans, Corsica, Sardinia) as in an older phylogeographic study that resulted in quite different conclusions about refugia locations, notably along the Italian peninsula (Fineschi et al. 2000). This example is a good illustration of the difficulties that still exist in drawing up robust biogeographical histories of cultivated trees who are indigenous somewhere in the Mediterranean region.
Intensive reforestation carried out in the NorthMediterranean region generates the translocation of forest species outside their natural range of distribution, and these practices may alter the phylogeographic structures for widely used taxa (e.g. Pinus brutia, Pinus halepensis, Pinus nigra, Pinus pinaster, Pinus pinea, Quercus suber). It happens also for much less used and unsuspected tree species such as the manna ash (Fraxinus ornus): in Southeastern France, this tree is native in the Maritime Alps but invasive further west, along some rivers of the Hérault department (Thébaud and Debussche 1991). Sometimes, a depauperate low genetic diversity together an intense human-induced movement for reforestation preclude any phylogeographic signal, as for the emblematic and widespread Pinus pinea (Vendramin et al. 2008). These frequent reforestation practices can blur the biogeographic signature of forest stands at the regional scale, with detrimental consequences for the conservation of local genetic resources.

\section{Conservation issues}

As many trees are threatened around the world (BGCI 2018), it is necessary to get an accurate assessment of the conservation status of the different tree taxa in a comprehensive biogeographical scheme and using the most robust data available, i.e. from the IUCN (2018). However, the IUCN Red List contains only a limited number of Mediterranean trees and some old or inadequate assessments should be reviewed again. The presence of only 19 Mediterranean trees considered to be threatened $(15 \mathrm{CR}+\mathrm{EN}+\mathrm{VU})$ or near threatened (4 NT) is probably not representative of the global level of threat that these woody contingent experiences in a region that has been managed, modified, and, in some places, heavily degraded by human activities for millennia (e.g. Thirgood 1981; Blondel et al. 2010). Indeed, only $7.7 \%$ of the 245 species and subspecies we identified are considered threatened according to the IUCN database, despite that the global contingent of the North Mediterranean trees includes 46 endemic trees that have a narrow distribution range. This is not surprising because at the world scale only a tiny percentage (11\%) of trees has been assessed by the IUCN Red List criteria, compared with other major species groups (Fauna and Flora International 2013).

Some rare Mediterranean endemic taxa (e.g. Abies pinsapo, Phoenix theophrasti), or trees with a patchy distribution along the coasts (e.g. Juniperus macrocarpa on sand dunes) face dramatic habitat destruction due to the exponential development of human infrastructure, often linked to mass tourism. Several rare and narrow endemic trees linked to wet habitats are not included in the current IUCN database, such as the Sardinian endemic Salix arrigonii, whereas another tree, Tamarix 
minoa, occurring in a unique locality of NW Crete on sandy river banks close to the sea (Villar et al. 2015), is quoted Data Deficient (DD). Among the other DD taxa, at least two characteristic taxa (Platanus orientalis, Vitex agnus-castus) currently experience a severe reduction of their populations due to the artificialization of their habitats, even if they still count a quite large number of populations.

Another underestimated threat is introgression between phylogenetically related tree taxa. This is the case of the group of black pines (Pinus nigra) where introgression risk is likely between Pinus nigra subsp. nigra, frequently planted for reforestation, and two other subspecies having a more restricted distribution range: subsp. dalmatica in Croatia, and subsp. salzmannii in France and Spain. Although infrequent and potentially beneficial for some traits, such gene flow from planted to native trees to could contribute to worsen local adaptation, for example to diseases such as Dothistroma sp. (Scotti-Saintagne et al. 2018).

From a geographical point of view, we must emphasize the role of the large Mediterranean islands, which include 11 of the 19 tree taxa currently present in the IUCN database. This shows the importance of these island ecosystems for the differentiation and persistence of taxonomically singular trees, but also the severe threats in these spatially restricted systems. This is the case of Sicily which includes three rare narrow endemics (Abies nebrodensis, Cytisus aeolicus, Zelkova sicula) among which the two latter are only present on some small islands of the Aeolian archipelago (Troia 2012). Some other narrow endemic trees (Genista tyrrhena from Aeolian and Pontine archipelagos in Italy, and Quercus alnifolia restricted to the Troodos range in Cyprus) are classified as least concern (LC), but due to their restricted range and population size these evaluations are probably too optimistic. A more precise risk analysis by region would also probably highlight the high level of threat to locally several Mediterranean trees. For example, the tyrrhenian insular endemic Genista etnensis which is ranked globally as LC is classified as critically endangered (CR) in Corsica. This is also the case of several trees with a patchy distribution in specialized mountain habitats such as Juniperus drupacea, J. foetidissima, J. thurifera, and Pinus heldreichii which are classified as LC as well. Some other locally threatened taxa (Buxus balearica, Rhododendron ponticum) with a highly restricted range in the N. Mediterranean region are not even considered in the IUCN database.

\section{Conclusion}

This study provides the first comprehensive assessment of tree distributions in the Mediterranean-European region. The present checklist includes an unsuspectedly high number of tree taxa (245 species and subspecies), with at least 44 taxa that are generally bushy but can express a true tree architecture under certain conditions ("cryptic trees"). This means that the Mediterranean-European region has almost 200 trees more than the Central European region. This taxonomic biodiversity is highest in the central-eastern part of the Mediterranean region, notably in the Apennino-Balkan province. We must also emphasize the role of some large Tyrrhenian islands (especially Sicily and Sardinia) that shelter a significant number of endemic trees. These areas are particularly important from the point of view of functional conservation because tree species richness is positively linked to higher levels of multiple ecosystem services (Gamfeldt et al. 2013), and rare species - like most of the Mediterranean endemic trees - support original and vulnerable function (Mouillot et al. 2013). But threats to this woody biodiversity are often significant and may especially affect trees with narrow distributions. However, the IUCN Red list includes so far only 19 Mediterranean trees considered to be threatened $(\mathrm{CR}+\mathrm{EN}+\mathrm{VU})$ or near threatened (NT). Therefore, the vulnerability of several of these trees is probably underestimated and further assessments are needed in the near future.

For Mediterranean trees favored or cultivated by man, sometimes for millennia, it is necessary to develop approaches combining phylogeography and paleoecology, at the scale of the distribution area specific to each taxon. This will allow a better estimate of the native status for each biogeographical area, and to consider the evolutionary dimension in the preservation of these trees.

This checklist represents the first step towards a better understanding of the diversity of trees in the Mediterranean region. The next step should be to improve the coverage in occurrences records for these tree taxa in the region in the existing tree species database (Noce et al. 2016; Serra-Diaz et al. 2017). These data will help to explore the key scientific questions associated to the drivers of the distribution pattern and to the shape of the species-area relationship. Quantitative investigations of ecological (e.g., climate, soil, disturbance) versus historical (e.g., past climate, genetic originality) drivers of current tree biodiversity can therefore be considered. This checklist will constitute also an essential background for functional and phylogenetic analyses of this key biological contingent for terrestrial ecosystems. The practical issues concern a better assessment of the threatened status of some these unappreciated trees within a highly human-modified region. We also hope such work will catalyze further assessment of tree diversity at the scale of the whole Mediterranean region (i.e. also North Africa and Middle-East) even if the data are still very complex to synthesize. 


\section{Additional file}

Additional file 1: Table S1. Checklist of the tree taxa (species and subspecies) occuring in theMediterranean-European region, from Portugal to Cyprus. The definition of the families follows the Angiosperm Phylogeny Group (APG III 2009; APG IV 2016). Theretained nomenclature of the tree taxa is compared with those of the Euro+Med database (http://www.emplantbase.org/home.html), the volume series Chorology of trees and shrubs in south-westAsia and adjacent regions (Browicz 19821996) and the World Checklist Kew. For the occurence of eachtree taxa in a country or a large island, we indicate the endemism status, the cultivated status, theautochthonous (native: N) or allochthonous (introduced: I) status. Taxa for which the presence is notconfirmed but possible are quoted as "putative presence », i.e."?". (XLSX 71 kb)

\section{Acknowledgments}

The authors thank Aggeliki Doxa (Institute of Applied and Computational Mathematics, Heraklion), Laetitia Hugot and Paula Spinosi (Conservatoire botanique national de Corse / Office de l'environnement de la Corse), Virgile Noble (Conservatoire botanique national méditerranéen), Salvatore Pasta (CNR Palermo), Estefanía Santos Barea (Universidad de Sevilla) for their help in acquiring the data or for their comments on the distribution or status of the different tree species.

\section{Funding}

This work was funded by the French Foundation for Research on Biodiversity (FRB) through its Centre for Synthesis and Analysis of Biodiversity data (CESAB) programme, as part of the WOODIV research project. ACM and MCB were funded by Labex OT-Med ( $n^{\circ}$ ANR-11-LABX-0061). The funders had no role in study design, data collection and analysis, decision to publish, or preparation of the manuscript.

\section{Availability of data and materials}

After acceptance data will be made publicly available as an additional file.

\section{Authors' contributions}

Conceived and designed the database: FM, DP, ACM, GB, PD, TN and AL. Analyzed the data: ACM and FM. Wrote the paper: FM, ACM and TN. All authors participated to the discussions leading to the framing of the manuscript during WOODIV workshops. All authors read, contributed suggestions and approved the final manuscript.

\section{Ethics approval and consent to participate}

Not applicable.

\section{Consent for publication}

Not applicable.

\section{Competing interests}

The authors declare that they have no competing interests.

\section{Author details}

${ }^{1}$ Aix Marseille Univ, Avignon Univ, CNRS, IRD, IMBE. Technopôle de I'Arbois-Méditerranée, cedex 4, BP 80, 13545 Aix-en-Provence, France. ${ }^{2}$ Faculty of Science, University of Zagreb, Horvatovac 102a, HR-10000 Zagreb, Croatia. ${ }^{3}$ Department of Biology, Division of Plant Biology, Laboratory of Botany, University of Patras, University Campus, 26504 Rio, Greece. ${ }^{4}$ Centro Conservazione Biodiversità, Dipartimento di Scienze della Vita e dell'Ambiente, Università degli Studi di Cagliari, Viale S. Ignazio da Laconi, 13, 09123 Cagliari, Italy. ${ }^{5}$ Departamento de Biologia Vegetal y Ecologia, Universidad de Sevilla, Apartado 1095, 41080 Sevilla, Spain. ${ }^{6}$ Department of Botany, Hungarian Natural History Museum, Pf. 137, Budapest 1431, Hungary. ${ }^{7}$ Sorbonne University, IEES Bât 44-34, cc 237. 4, Place Jussieu, Paris, France. ${ }^{8}$ Department of Agriculture, Food and Forest Sciences, University of Palermo, Viale delle Scienze bldg. 4, 90128 Palermo, Italy. ${ }^{9}$ INRA, UR629, Ecologie des forêts méditerranéennes, Avignon, France. ${ }^{10}$ Macedonian Academy of Sciences and Arts, Krste Misirkov 2, 1000 Skopje, Republic of Macedonia. ${ }^{11}$ EcoGozo, Regional Development Directorate - Ministry for Gozo, Flat 6, Sunset Court B, Triq Marsalforn, Xaghra, Gozo, Malta.
Received: 17 December 2018 Accepted: 28 February 2019 Published online: 19 March 2019

\section{References}

Alberdi Asensio I, Baycheva-Merger T, Bouvet A, Bozzano M, Caudullo G, Cienciala E, Corona P, Domínguez Torres G, Durrant TH, Edwards D, Estreguil C, Ferreti M, Fischer U, Freudenschuss A, Gasparini P, Ferreira PG, Hansen K, Hiederer R Inhaizer $\mathrm{H}$, Thorsen $\mathrm{B}$, Jonsson $\mathrm{R}$, Kastenholz $\mathrm{E}$, von Lengefeld AK, Köhl M, Korhonen K, Koskela J, Krumm F, Lanz A, Lasserre B, Levet A-L, Li Y, Lier M, Carrera JMM, Marchetti M, de Arano IM, Michel A, Moffat A, Nabuurs G-J, Oldenburger J, Parviainen J, Pettenella D, Prokofieva I, Quadt V, Rametsteiner E, Rinaldi F, Sanders T, San-Miguel-Ayanz J, Schuck A, Seidling W, Solberg B, Sotirov M, Ståhl G, Tomé M, Toth G, van Brusselen J, Verkerk H, Vítková L, Weiss G, Wildburguer C, Winkel G, Zasada M, Zingg A (2015) State of Europe's forests 2015. Ministerial Conference on the Protection of Forests in Europe. Forest Europe, Madrid 20-21 October 2015

APG III (2009) An update of the angiosperm phylogeny group classification for the orders and families of flowering plants: APG III. Bot J Linn Soc 161:105-121

APG IV (2016) An update of the angiosperm phylogeny group classification for the orders and families of flowering plants: APG IV. Bot J Linn Soc 181:1-20

Aradhya M, Velasco D, Ibrahimov Z, Toktoraliev B, Maghradze D, Musayev M, Bobokashvili Z, Preece JE (2017) Genetic and ecological insights into glacial refugia of walnut (Juglans regia L.). PLoS One 12(10):e0185974

Arrigoni PV (2006-2015) Flora dell'Isola di Sardegna, vols 1-6. Carlo Delfino editore, Sassari

Bacchetta G, Fenu G, Mattana E (2012) A checklist of the exclusive vascular flora of Sardinia with priority rankings for conservation. Anales del Jardín Botánico de Madrid 69:81-89

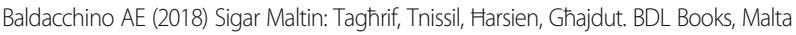

Baldacchino AE, Stevens DT (2000) Is-siġar Maltin - l-użu u l-importanza: seminar nazzjonali ta' ġurnata imlaqqa' I-Furjana, Malta, 24 ta' Novembru, 1998. Dipt. Ghall-Harsien tal-Ambejent, Malta

Barina Z, Mullaj A, Pifkó D, Somogyi G, Meco M, Rakaj M (2017) Distribution atlas of vascular plants in Albania. Hungarian Natural History Museum, Budapest

Bar-On YM, Phillips R, Milo R (2018) The biomass distribution on earth. PNAS 115(25):6506-6511

Bartolucci F, Peruzzi L, Galasso G, Albano A, Alessandrini A, Ardenghi NMG, Astuti G, Bacchetta G, Ballelli S, Banfi E, Barberis G, Bernardo L, Bouvet D, Bovio M, Cecchi L, Di Pietro R, Domina G, Fascetti S, Fenu G, Festi F, Foggi B, Gallo L, Gottschlich G, Gubellini L, lamonico D, Iberite M, Jiménez-Mejías $P$, Lattanzi $E$, Marchetti D, Martinetto E, Masin RR, Medagli P, Passalacqua NG, Peccenini S, Pennesi R, Pierini B, Poldini L, Prosser F, Raimondo FM, Roma-Marzio F, Rosati L, Santangelo A, Scoppola A, Scortegagna S, Selvaggi A, Selvi F, Soldano A, Stinca A, Wagensommer RP, Wilhalm T, Conti F (2018) An updated checklist of the vascular flora native to Italy. Plant Biosyst 152:179-303

Baumel A, Mirleau F, Pironon S, Nieto Feliner G, Bou Dagher Kharrat M, La Malfa S, Ouahmane L, Diadema K, Suc J-P, Juin M, Médail F, Le Galliot N, Sanguin $\mathrm{H}$, Viruel J (2018) The carob tree at the crossroad of domestication center and refugia hypotheses. II Joint Congress on Evolutionary Biology, Montpellier 19-22 August 2018

Beech E, Rivers M, Oldfield S, Smith PP (2017) GlobalTreeSearch: the first complete global database of tree species and country distributions. J Sustain Forest. https://doi.org/10.1080/10549811.2017.1310049

Besnard G, Rubio de Casas R (2016) Single vs multiple independent olive domestications: the jury is (still) out. New Phytol 209:466-470

BGCI (2018) GlobalTreeSearch online database. Botanic Gardens Conservation International, Richmond http://www.bgci.org/globaltree_search.php. Accessed 20 Nov 2018

Blondel J (2006) The 'design' of Mediterranean landscapes: a millennial story of humans and ecological systems during the historic period. Hum Ecol 34:713-729

Blondel J, Aronson J, Bodiou J-Y, Bœuf G (2010) The Mediterranean region: biological diversity in space and time, 2nd edn. Oxford University Press, Oxford

Browicz K (1982-1996) Chrorology of trees and shrubs in south-West Asia and adjacent regions. Vols 1-10 + supplement. Polish Academic of Sciences, Institute of dendrology, Kornik

Calleja EJ (2018) Trees and shrubs of the Maltese islands and their habitats. Nature Trust - FEE, Malta

Casha A (2015) Flora of the Maltese islands. 2nd edition. (privately published), Malta

Castroviejo S (1986-2015) Flora Iberica: Plantas vasculares de la Peninsula Ibérica e Islas Baleares, vol 20. Real Jardin Botanico \& CSIC, Madrid

Chilton L, Turland NJ (1997) Flora of Crete. Marengo publication, Hunstanton 
Cowling RM, Ojeda F, Lamont BB, Rundel PW, Lechmere-Oertel R (2005) Rainfall reliability, a neglected factor in explaining convergence and divergence of plant traits in fire-prone mediterranean-climate ecosystems. Glob Ecol Biogeogr 14:509-519

Dimopoulos P, Raus T, Bergmeier E, Constantinidis T, latrou G, Kokkini S, Strid A, Tzanoudakis D (2013) Vascular plants of Greece: an annotated checklist, vol 31. Botanic Garden and Botanical Museum Berlin-Dahlem; Athens: Hellenic Botanical Society Englera, Berlin, pp 1-372

Dimopoulos P, Raus T, Bergmeier E, Constantinidis T, latrou G, Kokkini S, Strid A, Tzanoudakis D (2016) Vascular plants of Greece: an annotated checklist. Supplement. Willdenowia 46(sup):S301-S347

Ellenberg H, Weber HE, Dull R, Wirth V, Werner W, Pauliben D (1991) Zeigerwerte von pflanzen in Mitteleuropa. Scripta Geobotanica 18:3-248

Fady B, Conord C (2010) Macroecological patterns of species and genetic diversity in vascular plants of the Mediterranean basin. Divers Distrib 16:53-64

Fahn A (1990) Plant anatomy, 4th edn. Pergamon Press, Oxford

FAO, Bleu P (2018) State of Mediterranean forests 2018. Food and agriculture Organization of the United Nations. Rome and Plan Bleu, Marseille

Fauna \& Flora International (2013) Looking closer, seeing the trees from the forest. http://www.globaltrees.org/. Accessed 20 Nov 2018

Fazan L, Stoffel M, Frey DJ, Pirintsos S, Kozlowski G (2012) Small does not mean young: age estimation of severely browsed trees in anthropogenic Mediterranean landscapes. Biol Conserv 153:97-100

Fineschi S, Taurchini D, Villani F, Vendramin GG (2000) Chloroplast DNA polymorphism reveals little geographical structure in Castanea sativa mill. (Fagaceae) throughout southern European countries. Mol Ecol 9:1495-1503

Galasso G, Conti F, Peruzzi L, Ardenghi NMG, Banfi E, Celesti-Grapow L, Albano A, Alessandrini A, Bacchetta G, Ballelli S, Mazzanti B, Barberis G, Bernardo L, Blasi C, Bouvet D, Bovio M, Cecchi L, Del Guacchio E, Domina G, Fascetti S, Gallo L, Gubellini L, Guiggi A, lamonico D, Iberite M, Jiménez-Mejías P, Lattanzi E, Marchetti D, Martinetto E, Masin RR, Medagli P, Passalacqua NG, Peccenini S, Pennesi R, Pierini B, Podda L, Poldini L, Prosser F, Raimondo FM, RomaMarzio F, Rosati L, Santangelo A, Scoppola A, Scortegagna S, Selvaggi A, Selvi F, Soldano A, Stinca A, Wagensommer RP, Wilhalm T, Bartolucci F (2018) An updated checklist of the vascular flora alien to Italy. Plant Biosyst 152:1-37

Gamfeldt L, Snäll T, Bagchi R, Jonsson M, Gustafsson L, Kjellander P, Ruiz-Jaen MC, Fröberg M, Stendahl J, Philipson CD, Mikusinski G, Andersson E, Westerlund B, Andrén H, Moberg F, Moen J, Bengtsson J (2013) Higher levels of multiple ecosystem services are found in forests with more tree species. Nat Commun 4:1340. https://doi.org/10.1038/ncomms2328

Giardina G, Raimondo FM, Spadaro V (2007) A catalogue of plants growing in Sicily. Bocconea 20:5-582

Gschwantner T, Schadauer K, Vidal C, Lanz A, Tomppo E, di Cosmo L, Robert N, Englert Duursma D, Lawrence M (2009) Common tree definitions for national forest inventories in Europe. Silv Fenn 43:303-321

Hand R, Hadjikyriakou GN, Christodoulou CS (2011) Flora of Cyprus - a dynamic checklist. http://www.flora-of-cyprus.eu. Accessed 20 Nov 2018

IUCN (2018) The IUCN Red List of threatened species. http://www.iucnredlist.org. Accessed 20 Nov 2018

Jeanmonod D, Gamisans J (2013) Flora Corsica, 2nd edn. In: Bulletin de la Société Botanique du Centre-Ouest, Nouvelle Série, Numéro Spécial, vol 39. Société Botanique du Centre Ouest, pp 1-1074

Jogan N, Bacic T, Frajman B, Leskovar I, Naglic D, Podobnik A, Rozman B, StrgulcKrajsek S, Trcak B (2001) Materials for the atlas of flora of Slovenia. Center za Kartografijo Favne in Flore, Miklavž na Dravskem Polju

Khadari B, Grout C, Santoni S, Kjellberg F (2005) Contrasted genetic diversity and differentiation among Mediterranean populations of Ficus carica L.: a study using mtDNA RFLP. Genet Resour Crop Evol 52:97-109

Lens F, Davin N, Smets E, del Arco M (2013) Insular woodiness on the Canary Islands: a remarkable case of convergent evolution. Int J Plant Sci 174:992-1013

Leuschner C, Meier IC (2018) The ecology of central European tree species: trait spectra, functional trade-offs, and ecological classification of adult trees. Perspect Plant Ecol Evol Syst 33:89-103

Marino P, Castiglia G, Bazan G, Domina G, Guarino R (2014) Tertiary relict laurophyll vegetation in the Madonie mountains (Sicily). Acta Bot Gallica: Bot Lett 161:47-61

Mattioni C, Martin MA, Pollegioni P, Cherubini M, Villani F (2013) Microsatellite markers reveal a strong geographical structure in European populations of Castanea sativa (Fagaceae): evidence for multiple glacial refugia. Am J Bot 100:951-961

Mazzocchi GB (1969) Trees and shrubs in the Maltese islands. Food and Agriculture Organisation of the United Nations, Rome
Mazzoleni S, Di Pascale G, Mulligan M, Di Martino P, Rego F (2004) Recent dynamics of Mediterranean vegetation and landscape. Wiley, London Médail F (2008) Ecosystems: Mediterranean. In: Jørgensen SE, Fath B (eds) Encyclopedia of ecology, vols 3, 5. Elsevier, Oxford, pp 2296-2308

Médail F (2017) The specific vulnerability of plant biodiversity and vegetation on Mediterranean islands in the face of global change. Region Environ Change 17:1775-1790

Médail F, Diadema K (2009) Glacial refugia influence plant diversity patterns in the Mediterranean Basin. J Biogeogr 36:1333-1345

Médail F, Myers N (2004) Mediterranean Basin. In: Mittermeier RA, Robles Gil P (eds) Hotspots revisited: Earth's biologically richest and most endangered terrestrial ecoregions. CEMEX (Monterrey), Conservation International, Washington and Agrupación Sierra Madre, pp 144-147

Médail F, Quézel P (1997) Hot-spots analysis for conservation of plant biodiversity in the Mediterranean Basin. Ann Missouri Bot Gard 84:112-127

Mercuri AM, Bandini Mazzanti M, Florenzano A, Montecchi MC, Rattighieri E (2013) Olea, Juglans and Castanea: the OJC group as pollen evidence of the development of human-induced environments in the Italian peninsula. Quatern Int 303:24-42

Mifsud S (2002-2014) MaltaWildPlants.com - an online flora of the Maltese islands. http://www.maltawildplants.com. Accessed 20 Nov 2018

Migliore J, Baumel A, Juin M, Médail F (2012) From Mediterranean shores to central Saharan mountains: key phylogeographical insights from the genus Myrtus. J Biogeogr 39:942-956

Molina-Venegas M, Aparicio A, Slingsby JA, Lavergne S, Arroyo J (2015) Investigating the evolutionary assembly of a Mediterranean biodiversity hotspot: deep phylogenetic signal in the distribution of eudicots across elevational belts. J Biogeogr 42:507-518

Montoya D, Rodríguez MA, Zavala MA, Hawkins BA (2007) Contemporary richness of holarctic trees and the historical pattern of glacial retreat. Ecography 30:173-182

Mouillot D, Bellwood DR, Baraloto C, Chave J, Galzin R, Harmelin-Vivien M, Kulbicki M, Lavergne S, Lavorel S, Mouquet N, Paine CET, Renaud J, Thuiller W (2013) Rare species support vulnerable functions in high-diversity ecosystems. PLoS Biol 11(5):e1001569. https:/doi.org/10.1371/journal.pbio.1001569

Nikolić T (2004) Flora Croatica database. Faculty of Science, University of Zagreb. http://hirc.botanic.hr/fcd/. Accessed 20 Nov 2018

Noce S, Collalti A, Valentini R, Santini M (2016) Hot spot maps of forest presence in the Mediterranean basin. iForest - Biogeosc Forest 9:766-774

Olson DM, Dinerstein E, Wikramanayake ED, Burgess ND, Powell GVN, Underwood EC, D'Amico JA, Itoua I, Strand HE, Morrison JC, Loucks CJ, Allnutt TF, Ricketts TH, Kura Y, Lamoreux JF, Wettengel WW, Hedao P, Kassem KR (2001) Terrestrial ecoregions of the world: a new map of life on earth. A new global map of terrestrial ecoregions provides an innovative tool for conserving biodiversity. BioScience 51:933-938

Olson ME, Soriano D, Rosell JA, Anfodillo T, Donoghue MJ, Edwards EJ, LeónGómez C, Dawson T, Camarero Martínez JJ, Castorena M, Echeverría A, Espinosa Cl, Fajardo A, Gazol A, Isnard S, Lima RS, Marcati CR, Méndez-Alonzo R (2018) Plant height and hydraulic vulnerability to drought and cold. PNAS 115:7551-7556

Palamarev E (1989) Paleobotanical evidences of the tertiary history and origin of the Mediterranean sclerophyll dendroflora. Plant Syst Evol 162:93-107

Pignatti S (1982) Flora d'Italia. 3 vol. Edagricole, Bologna.

Postigo Mijarra JM, Barrón E, Manzaneque FG, Morla C (2009) Floristic changes in the Iberian Peninsula and Balearic Islands (south-West Europe) during the Cenozoic. J Biogeogr 36:2025-2043

Quézel P, Médail F (2003) Ecologie et biogéographie des forêts du bassin méditerranéen. Elsevier, Paris

Raunkiær CC (1934) The life form of plants and statistical plant geography. Oxford University Press, Oxford

Rivas-Martínez S, Asensi A, Garretas B, Valle F, Cano E, Costa M, Luisa López M, Díaz T, Fernández Prieto JA, Llorens L, Del Arco AM, Osorio VE, Luis Pérez de Paz P, Wildpret W, Reyes-Betancort J, García Gallo A, Rodríguez O, Acebes J, Gaisberg M, Soriano P (2007) Mapa de series, geoseries y geo-permaseries de vegetazión de España. Itinera Geobot 17:5-436

Rivas-Martínez S, Penas A, Díaz TE (2004) Biogeographic map of Europe. University of León, Spain http://www.globalbioclimatics.org/form/maps.htm. Accessed 20 Nov 2018

Roces-Díaz JV, Jiménez-Alfarod B, Chytrý M, Díaz-Varelag ER, Álvarez-Álvarez $P$ (2018) Glacial refugia and mid-Holocene expansion delineate the current distribution of Castanea sativa in Europe. Palaeogeogr Palaeoclim Palaeoecol 491:152-160 
Rodríguez-Sánchez F, Guzmán B, Valido A, Vargas P, Arroyo J (2009) Late Neogene history of the laurel tree (Laurus L., Lauraceae) based on phylogeographical analyses of Mediterranean and Macaronesian populations. J Biogeogr 36:1270-1281

San-Miguel-Ayanz J, de Rigo D, Caudullo G, Houston Durrant T, Mauri A, Tinner W, Ballian D, Beck P, Birks HJB, Eaton E, Enescu CM, Pasta S, Popescu I, Ravazzi C, Welk E, Abad Viñas R, Azevedo JC, Barbati A, Barredo Jl, Benham SE, Boca R, Bosco C, Caldeira MC, Cerasoli S, Chirici G, Cierjacks A, Conedera M, Da Ronch F, Di Leo M, García-Viñas Jl, Gastón González A, Giannetti F, Guerrero Hue N, Guerrero Maldonado N, López MJ, Jonsson R, Krebs P, Magni D, Mubareka S, Nieto Quintano P, Oliveira S, Pereira JS, Pividori M, Räty M, Rinaldi F, Saura S, Sikkema R, Sitzia T, Strona G, Vidal C, Vilar L, Zecchin B (2016) European atlas of forest tree species. Publication Office of the European Union, Luxembourg

Scotti-Saintagne C, Fady B, Turion N, Giovannelli G (2018) Le pin de Salzmann: une espèce à protéger. Garance Voyageuse 123:7-12

Serra-Diaz JM, Enquist BJ, Maitner B, Merow C, Svenning J-C (2017) Big data of tree species distributions: how big and how good? Forest Ecosyst 4:30. https://doi.org/10.1186/s40663-017-0120-0

Sociedade Portuguesa de Botânica (2014) Flora-On: Flora de Portugal Interactiva. http://www.flora-on.pt. Accessed 20 Nov 2018.

Strid A (2016) Atlas of the Aegean Flora. (part 1: text \& plates; part 2: maps). Botanic Garden and Botanical Museum, Berlin. Englera 33 (1 \& 2): part 1, pp 1-700; part 2, pp 1-878

Svenning J-C, Skov F (2007) Ice age legacies in the geographical distribution of tree species richness in Europe. Glob Ecol Biogeogr 16:234-245

Thébaud C, Debussche M (1991) Rapid invasion of Fraxinus ornus L. along the Hérault river system in southern France: the importance of seed dispersal by water. J Biogeogr 18:7-12

Thirgood JV (1981) Man and the Mediterranean forest: a history of resource depletion. Academic Press, London and New York

Tison J-M, Jauzein P, Michaud H (2014) Flore de la France méditerranéenne continentale. Conservatoire botanique national méditerranéen de Porquerolles \& Naturalia Publications, Turriers

Troia A (2012) Insular endemism in the Mediterranean vascular flora: the case of the Aeolian Islands (Sicily, Italy). Biodiv J 3:369-374

Tutin TG, Heywood VH, Burges NA, Valentine DH, Walters SM, Webb DA (19641993) Flora Europaea. Vols 1-5 \& Vol. 1 second edition. Cambridge University Press, Cambridge

Ucchesu M, Peña-Chocarro L, Sabato D, Tanda G (2015) Bronze age subsistence in Sardinia (Italy): cultivated plants and wild resources. Veget Hist Archaeobot 24:343-355

Vendramin GG, Fady B, González-Martínez SC, Hu FS, Scotti I, Sebastiani F, Soto A, Petit RJ (2008) Genetically depauperate but widespread: the case of an emblematic Mediterranean pine. Evolution 62:680-688

Villar JL, Turland NJ, Juan A, Gaskin JF, Alonso MA, Crespo MB (2015) Tamarix minoa (Tamaricaceae), a new species from the island of Crete (Greece) based on morphological and plastid molecular sequence data. Willdenowia 45:161-172

Vít P, Douda J, Krak K, Havrdová A, Mandák B (2017) Two new polyploid species closely related to Alnus glutinosa in Europe and North Africa-an analysis based on morphometry, karyology, flow cytometry and microsatellites. Taxon 66:567-583

WWF (2001) The Mediterranean forests. A new conservation strategy, WWF Mediterranean Programme Office, Rome

\section{Submit your manuscript to a SpringerOpen ${ }^{\circ}$ journal and benefit from:}

- Convenient online submission

- Rigorous peer review

- Open access: articles freely available online

- High visibility within the field

- Retaining the copyright to your article

Submit your next manuscript at $\boldsymbol{\nabla}$ springeropen.com 